\title{
"CONSTRUIR UMA OUTRA ALDEIA": VÍNCULOS SOCIAIS E TERRITORIAIS NO PROCESSO DE RETOMADA, ALDEIA TUPINAMBÁ DE SERRA DO PADEIRO, BAHIA
}

\author{
DANIELA FERNANDES ALARCON ${ }^{1}$
}

$U n B$

\begin{abstract}
RESUMO: Este artigo, baseado em pesquisa etnográfica, debruça-se sobre o processo de recuperação territorial que vem sendo levado a cabo pelos Tupinambá da aldeia Serra do Padeiro (sul da Bahia) na última década. Mais especificamente, focaliza as retomadas de terra, principal forma de ação política desenvolvida contemporaneamente pelo grupo. Em definição sucinta, pode-se dizer que as retomadas consistem em processos de recuperação, pelos indígenas, de áreas por eles tradicionalmente ocupadas, no interior das fronteiras da Terra Indígena Tupinambá de Olivença, já delimitada, e que se encontravam em posse de não índios. Engajados no processo de "construção da aldeia", os indígenas estão deixando as posições de subordinação que ocupavam na sociedade regional, especialmente como mão de obra precária em fazendas de cacau, e voltando a se dedicar às atividades que desenvolviam tradicionalmente (como agricultura em pequena escala, criação de animais, caça, pesca e coleta). Vêm, ainda, atualizando sua história e projetando a trajetória futura do grupo étnico. Neste texto, buscarse-á demonstrar as relações entre o processo de retomada e a manutenção e o fortalecimento da identidade étnica tupinambá, dos laços sociais e territoriais do grupo.
\end{abstract}

PALAVRAS-CHAVE: Povos indígenas; Retomadas de terras; Tupinambá.

ABSTRACT: This article, based on ethnographic research, considers the process by which, in the last decade, the Tupinambá people of Serra do Padeiro (in Southern Bahia, Brazil) have retaken possession of its traditionally occupied lands. More specifically, it focuses on the retomadas de terras, the main form of political action developed by the group nowadays. In a short definition, the retomadas can be presented as processes by which the Indigenous community retakes possession of its traditionally occupied lands -which were in the hands of non-Indigenous people-, which fall within the borders of the Terra Indigena Tupinamba de Olivença. By retaking areas, they have been able to leave behind their old positions amidst the regional society (especially as workers living in precarious conditions in cocoa farms) and to resume traditional activities, such as small-scale farming, hunting, fishing and collecting. Also, they have been revisiting their history and redefining their future trajectory. This article aims to demonstrate the relations between the retaking process and the maintenance and reinforcement of the ethnic identity of the Tupinambá people, their social and territorial bonds.

KEYWORDS: Indigenous peoples; Retaking of lands; Tupinambá.

\footnotetext{
${ }^{1}$ Mestre em Ciências Sociais (UnB), pesquisadora associada ao Laboratório de Estudos e Pesquisas em Movimentos Indígenas, Políticas Indigenistas e Indigenismo (Laepi/UnB). E-mail: alarcon.df@gmail.com.
} 


\section{Introdução}

A única chance de sobrevivência de alguém mordido por uma cobra-cipó, explicou-me certa vez uma indígena tupinambá da aldeia Serra do Padeiro, no sul da Bahia, é correr em direção a um formigueiro, chegar antes da cobra, e comer três torrões de terra. Caso contrário, não há o que fazer: a cobra rumará à cumeeira da casa da vítima e aí esperará, pacientemente, pois sabe que em breve deixará o local, acompanhando o caixão ${ }^{2}$. O receituário tupinambá preserva fórmulas para o combate de um sem fim de enfermidades, à base dos mais variados ingredientes, que têm em comum apenas o fato de levarem em seu preparo um torrão de terra. "A terra que a formiga joga para cima, ali é o remédio; ela não faz isso [revolve a terra] à toa", disse-me uma indígena. Também presenciei quando uma senhora, ao ver chegar da roça o neto ensanguentado, com um corte profundo no joelho, tomou o facão com que ele havia se ferido e o cravou na terra. Explicou-me, em seguida, que esse procedimento faria o sangramento estancar.

A terra, para os Tupinambá da Serra do Padeiro, tem atributos curativos. Porém, ao passo que para curar um indivíduo alguns torrões de terra bastariam, a reparação das violações cometidas historicamente contra os Tupinambá e a restituição das possibilidades de desenvolverem sua trajetória como povo repousariam, necessariamente, na recuperação do território como um todo. Situada nos municípios de Buerarema, llhéus e Una, sul do estado da Bahia, a Terra Indígena (TI) Tupinambá de Olivença estende-se por uma região historicamente associada à agricultura e ao turismo. Sua história vincula-se a um longo processo de territorialização da população indígena da região, que tem como marco o

\footnotetext{
${ }^{2}$ Esta narrativa intrigou-me, pois a cobra-cipó era sempre referida pelos Tupinambá como não peçonhenta. Quando falei dessa aparente contradição a minha interlocutora, ela confirmou que, de fato, nunca ouvira dizer que alguém tivesse sido vitimado por uma cobra-cipó, mas confirmou que era essa a cobra mencionada na história (ouvida de seus antepassados). Talvez o procedimento descrito estivesse relacionado, originalmente, a outra cobra, havendo a narrativa se alterado ao longo de sua transmissão. Ou talvez não: estudos recentes têm apontado que, ao contrário do que se imagina, a mordida das espécies genericamente conhecidas como cobra-cipó pode matar (SALOMÃO et al., 2003).
} 
DANIELA FERNANDES ALARCON - "Construir uma outra aldeia”...

estabelecimento do aldeamento jesuítico de Nossa Senhora da Escada, em 1680, no que hoje corresponde à sede do distrito de Olivença, localizada a cerca de $21 \mathrm{~km}$ da cidade de llhéus ${ }^{3}$. Ao longo do tempo, os indígenas tiveram as áreas em sua posse drasticamente reduzidas, conforme grandes porções do território eram fixadas em fazendas pretensamente pertencentes a não índios. No século $x x$, a expansão capitalista sobre essas terras de ocupação tradicional, que visava a conversão de um território culturalmente construído em fator de produção, intensificou-se.

Em maio de 2002, o Estado brasileiro reconheceu oficialmente a existência do povo Tupinambá4. Dois anos depois, respondendo às demandas indígenas, a Fundação Nacional do Índio (Funai) iniciou o procedimento de identificação e delimitação da TI. Transcorridos cinco anos, o órgão indigenista aprovou o relatório circunstanciado, delimitando a TI em uma área de 47.376 ha. No sentido leste-oeste, ela se prolonga da costa marítima à cadeia montanhosa conformada pelas serras das Trempes, do Serrote e do Padeiro, e, no sentido norte-sul, do rio Cururupe à Lagoa do Mabaço. A área é recoberta pela Mata Atlântica e ecossistemas associados; nas últimas décadas, contudo, a expansão das atividades agrícolas na região reduziu drasticamente a vegetação nativa, restando poucas áreas bem preservadas. Quando da conclusão deste artigo, o processo demarcatório ainda estava em curso.

Não se dispõe de dados precisos acerca do número de habitantes indígenas da TI. Estima-se, segundo dados da Fundação Nacional de Saúde/Ministério da Saúde (Funasa/MS) para 2009, que a área seja habitada por cerca de 4.700 índios. Sabendo-se, contudo, que no marco do processo de recuperação territorial a população tem crescido substancialmente, pode-se afirmar com relativa segurança que esses números estão defasados. A população distribui-se por diferentes

\footnotetext{
${ }^{3} \mathrm{O}$ processo de territorialização pode ser compreendido como "uma intervenção da esfera política que associa - de forma prescritiva e insofismável - um conjunto de indivíduos e grupos a limites geográficos bem determinados" (OLIVEIRA FILHO, 1998, p. 56). Ainda conforme essa caracterização, a territorialização passa, necessariamente, pela "reelaboração da cultura e da relação com o passado" (OLIVEIRA FILHO, 1998, p. 55). Contudo, alerta o antropólogo, esse processo "não deve jamais ser entendido simplesmente como de mão única, dirigido externamente e homogeneizador", posto que ele é atualizado pelos povos indígenas (OLIVEIRA FILHO, 1998, p. 60). Para uma reconstituição do processo de territorialização dos Tupinambá, ver Alarcon (2013).

4 Note-se que, à época, o Brasil ainda não adotara a Convenção 169 da Organização Internacional do Trabalho (OIT), que determina a autoidentificação como critério de reconhecimento de grupos indígenas.
} 
DANIELA FERNANDES ALARCON - "Construir uma outra aldeia”...

localidades espalhadas pela $\mathrm{TI}$, unidas historicamente por vínculos de parentesco e pela partilha de uma identidade comum. Na porção mais interior da TI, situa-se a aldeia Serra do Padeiro, sobre a qual este artigo se debruça e onde vivem cerca de mil indígenas, conforme dados da Associação dos Índios Tupinambá da Serra do Padeiro (AITSP) para 2012.

Desde 2004 os indígenas vêm levando a cabo ações coletivas conhecidas como retomadas de terras. Em uma definição sucinta, podese afirmar que as retomadas consistem em processos de recuperação, pelos indígenas, de áreas por eles tradicionalmente ocupadas, no interior das fronteiras da TI, e que se encontravam em posse de não índios. $\mathrm{Na}$ aldeia Serra do Padeiro, dezenas de fazendas foram ocupadas até o momento, formando uma espécie de anel em torno da afloração rochosa que dá nome à aldeia e que é considerada a "morada dos encantados" 5 . Antes do início do processo de retomada, os indígenas viviam no interior de fazendas (mantendo com os pretensos proprietários dessas áreas relações de meação ou trabalho assalariado, entre outras); em pequenos sítios, que haviam logrado manter em sua posse, a despeito do avanço dos não índios; ou haviam se mudado para outras localidades, como sedes de municípios da região ou metrópoles do centro-sul do país. Apesar de os indígenas, ao longo da última década, terem ampliado significativamente a área que ocupam, esta permanece descontínua, já que persistem no território fazendas e sítios em posse de não índios. Como me explicou uma jovem indígena, trata-se de um labor de (re)construção:

Os encantados vieram e disseram que teríamos que construir uma outra aldeia para dar descanso a essas pessoas que foram assassinadas inocentemente. Porque elas foram proibidas de construir sua sina. Existe uma outra vida, e pode ser junto com a da gente também. Para isso, esta terra teria que ser afirmada.

Neste artigo, buscarei descrever alguns elementos do processo de "construção da aldeia", no marco da retomada territorial, considerada pelos Tupinambá condição essencial para o desenvolvimento de

\footnotetext{
${ }^{5}$ Os "encantados" são entidades não humanas centrais na cosmologia tupinambá, que habitam o território e são também referidas como "caboclos". A expressão "morada dos encantados" dá título à dissertação de mestrado da antropóloga Patricia Navarro de Almeida Couto, primeiro trabalho acadêmico a analisar a religiosidade na Serra do Padeiro (COUTO, 2008).
} 
projetos de vida autônoma. Entendo que o caso tupinambá enquadra-se no que seria um "processo de reconstrução da indianidade concernente ao Nordeste", em que, a despeito das especificidades de cada povo, seria possível identificar trajetórias análogas e a conformação de um “'modelo' de organização e cultura étnicas” (CARVALHO, 2011, p. 337338). Nas próximas seções, procurarei demonstrar que as retomadas de terras estão dialeticamente relacionadas à atualização da identidade étnica tupinambá, dos vínculos sociais e territoriais do grupo. As informações em que se fundamenta este artigo foram produzidas no âmbito de uma pesquisa de mestrado acerca das retomadas de terras realizadas pelos Tupinambá da aldeia Serra do Padeiro, concluída no início de 2013, que contemplou uma incursão etnográfica ao território Tupinambá, com quatro meses de duração. Note-se que todos os depoimentos aqui reproduzidos foram transcritos conforme os padrões da chamada norma culta e que, em algumas passagens do texto, pseudônimos são utilizados, com o intuito de resguardar a intimidade e a segurança de meus interlocutores.

\section{A cura da terra}

Houve um ano em que a terra adoeceu. Não se trata de metáfora; isso se deu precisamente em 1947, contou-me um indígena a quem chamarei de João. À época dos fatos, João não era ainda nascido, mas ele recorda o que seu pai lhe dizia. "O pai falava: estava na mata e viu turvando; foram para casa, as galinhas foram para o poleiro, ficou o dia todo assim. No dia seguinte, abriu"6. Mas, em seguida, veio a febre, uma devastadora epidemia de paludismo. "O povo vivia tremendo", contou-me uma senhora que, nessa época, era moça. "Até o beré dentro da água tremia", disse outra indígena7. "A pessoa estava enterrando um e já caía no túmulo, ou então chegava em casa e já estava doente", completou seu João. Seu pai enviuvou várias vezes; diz-se que teve, no total, 18 cônjuges e 32 filhos, boa parte dos quais morreram de malária e outras

\footnotetext{
${ }^{6}$ Esse episódio pode guardar relação com a ocorrência de um eclipse total do sol em 20 de maio de 1947 (COROADAS, 1947).

${ }^{7}$ Beré é um peixe de água doce comum na Serra do Padeiro.
} 
DANIELA FERNANDES ALARCON - "Construir uma outra aldeia”...

enfermidades contagiosas. A terra, por sua vez, perdeu a fertilidade: pragas começaram a proliferar inclusive em espécies que antes não eram atingidas. Em 1951, ocorreu a primeira "seca grande" de que têm lembrança os indígenas da Serra do Padeiro ${ }^{8}$. Molharam os pés de São José no rio de Una, mas a chuva demorou a cair ${ }^{9}$. Os bichos, as gentes, os encantados e outras classes de seres recuaram; alguns desapareceram. Ainda hoje, a terra está em recuperação.

Parece-me muito significativo o fato de, em narrativas de seu João e de outros indígenas, terra, índios e encantados aparecerem intimamente conectados - a enfermidade da terra desdobra-se na doença massiva que acomete os indígenas, provocando o recuo destes e dos encantados. Além disso, é crucial ter em mente que a doença da terra coincide com a intensificação da penetração de não índios no território Tupinambá, já no século Xx. Note-se que, a partir do último quartel do século XIX, a região sul da Bahia passou a se constituir como a principal fronteira agrícola do estado (GARCEZ, 1977). A penetração de não índios na Serra do Padeiro, contudo, só tomaria escala décadas depois. Transcorridas mais de seis décadas do marco inicial do adoecimento da terra, é comum que indígenas descrevam o processo de recuperação territorial como "retorno", "libertação" ou mesmo "cura" da terra, aludindo a profecias nesse sentido, que proliferaram durante todo o período de expropriação territorial. Nesta seção, aproximar-nos-emos do processo de retomada territorial nessa acepção: como cura da terra.

De diferentes maneiras, borrando as fronteiras imaginadas entre natureza e cultura, os Tupinambá buscam expressar as relações íntimas que guardam com o território, explicando, com isso, a vastidão de seus conhecimentos territoriais (ALARCON, 2013, p. 181-193). Segundo sua cosmologia, os encantados são os donos da terra, na qual os indígenas estão autorizados a viver e da qual estão destinados a cuidar. Decorre daí uma característica fundamental da relação entre índios e território, expressa no par de conceitos zelar/controlar. Aos índios é permitido, pelos encantados, empreender alterações no ambiente. Podem, por exemplo, suavizar ladeiras muito íngremes, para proporcionar mais segurança no deslocamento dos estudantes, ou encanar a água

\footnotetext{
${ }^{8}$ Uma nova grande seca teve lugar em 1971.

${ }^{9}$ Em outra versão, Santo Antônio.
} 
DANIELA FERNANDES ALARCON - "Construir uma outra aldeia”...

proveniente de fontes, valendo-se da gravidade ou de bombas, para abastecimento doméstico. Devem, sobretudo, zelar o território, isto é, protegê-lo, cuidá-lo, defendê-lo. O riacho fica mais belo por ser frequentado; quando a pesca é cotidiana, ele se torna mais limpo, em decorrência do movimento das redes. Também os animais assumiriam tarefas de zelo - as piabas, por exemplo, "são a limpeza do rio". Depois de encanada a água, o caminho que levava a um ribeirão ao qual não mais se acorria cotidianamente ia sumindo e, quando transposto, poderia motivar um lamento melancólico. Quando passamos sob um craveiro-daíndia, uma indígena contou-me que pedira recentemente a seu cônjuge que podasse a árvore de determinada maneira, para que a copa ficasse "rodada" ("vai ficar mais bonita").

Soube também que os indígenas plantaram em alguns pontos do território cabaceiras e palmeiras - as primeiras, para aproveitamento das cabaças, com as quais faziam maracás; as segundas, "para os pássaros voltarem", já que delas se alimentavam algumas espécies. Os indígenas planejam também construir viveiros de espécies nativas, para reflorestamento. Assim, intervenções no território ocorrem cotidianamente; contudo, erraria quem pensasse que controlá-lo era uma faculdade humana. Certa vez, vi o cacique Babau (Rosivaldo Ferreira da Silva) discordar de alguém que reclamava das chuvas frequentes, que faziam com que as aulas muitas vezes tivessem de ser suspensas: "Não podemos culpar a natureza, temos que aprender a conviver com a chuva e encontrar soluções". "Não há matemática que controle a natureza", disse-me em outra ocasião.

Seguindo a determinação do zelo/controle, após a realização de uma ação de retomada, o espaço da fazenda sofre transformações paulatinas. Quando estive em campo, muito se falava sobre o estado de abandono em que foram encontradas construções e roças: aqui era "uma tiririca medonha", que os índios se esforçaram para roçar; o mato alto impedia que tal casa fosse avistada da estrada; outra parecia um "chiqueiro" ("tinha garrafas por todo lado, cobra brava, que bate, morde e mata"); os morcegos dominavam aquela casa-sede (o cheiro dos animais ainda não saíra de todo). Quanto ao cacau, empregados ou meeiros "só faziam colher, não zelavam as roças". Nas falas, era comum a falta de zelo dos fazendeiros para com o território aparecer como um 
agravante ao ato expropriatório. A retomada da fazenda São José, por exemplo, foi motivada, basicamente, por duas razões: a área "não era bem zelada" e o pretenso proprietário, ao que parece, mantinha um trabalhador em condições análogas à escravidão. Ao apresentar essas narrativas, os indígenas contrapunham o estado de deterioração em que encontraram as fazendas ao cuidado que vinham imprimindo ao espaço.

Nas áreas retomadas, permanecem os cultivos já estabelecidos geralmente, pés de cacau e seringa - e são introduzidas novas roças, principalmente de mandioca e banana. Cercas e porteiras costumam ser mantidas; em alguns casos, são inclusive reforçadas, por questões de segurança. A perspectiva é de, no futuro, abolir algumas delas; contudo, enquanto perdurar a presença de não índios no território, isso não será possível. As construções previamente existentes nas fazendas também permanecem em pé (conheço apenas uma exceção, também relacionada à segurança dos indígenas), sendo adaptadas às necessidades dos novos moradores.

Antigas casas de trabalhadores, diminutas e por vezes mal iluminadas, tiveram seus espaços internos reconfigurados, foram ampliadas e pintadas, de modo a se tornarem mais salubres, cômodas e bonitas. Novas intervenções eram planejadas, para uma próxima safra ou para o momento em que a família se sentisse mais segura quanto a sua permanência no local e à não realização de operações policiais violentas, destinadas à reintegração de posse de áreas retomadas. Construções que antes tinham outras destinações (como depósitos, garagens e barcaças) foram modificadas para se tornarem moradias. Finalmente, novas casas e farinheiras também foram erigidas. Nas primeiras retomadas, houve quem construísse casas de sopapo (taipa); a maioria, contudo, ergueu casas de madeira, cobertas por telhas de amianto. Em 2012, alguns indígenas que haviam levantado casas de madeira em áreas retomadas estavam ampliando-as, construindo as novas partes em concreto, e planejavam substituir, assim que possível, as partes antigas por cômodos de alvenaria.

Além dessas modificações mais visíveis, vale comentar um conjunto de transformações sutis, que me parecem muito significativas quando se trata de refletir sobre a (re)apropriação, pelos índios, do território outrora transformado em fazenda. Era raro passar pelos fundos ou pela lateral de 
uma casa e não deparar com uma horta. Quando ela estava ausente, encontravam-se uma ou duas espécies úteis cultivadas pelos moradores ou, no mínimo, se era informado sobre a intenção de constituírem sua horta. "Onde eu moro, eu gosto de plantar minhas ervas", disse-me uma indígena. Era uma frase repetida aqui e ali, com poucas variações, que indicava como o estabelecimento de vínculos com o espaço de morada (a casa e seu entorno) passava, geralmente, pelo ato de cultivá-lo10. "A terra come quem anda sobre ela", disse o cacique Babau certa ocasião, "quando a gente planta, ela come também, mas come mais devagar". Na Futurama, retomada em 2004, uma indígena que ali vivia comentou, indicando amoreiras, pés de mamão e cupuaçu em torno de sua casa: "Onde tua vista alcançar, fomos nós que plantamos".

Fruteiras (mais perenes que hortas e jardins) indicam os lugares das casas antigas, de parentes vivos e mortos, no meio da mata. Nas retomadas, o desenvolvimento dos cultivos serve por vezes como marcador temporal ou materialização de laços com vizinhos, parentes e compadres, doadores de sementes ou mudas. As histórias de certos pés de frutas entrelaçam-se às histórias familiares - é o caso de um pé de jambre cuja idade exata é conhecida por uma senhora, pois, ao plantálo, ela sentia "as dores" de um de seus filhos, prestes a nascer. Algumas vezes a vi lançar olhares complacentes em direção à árvore, que, segundo ela, depois de velha, tornou-se "lerda", demorando a frutificar ${ }^{11}$.

Os cultivos servem, ainda, como forma de inscrever no território vínculos com aliados políticos. Em maio de 2012, visitei com alguns indígenas o Projeto de Assentamento Terra Vista, no vizinho município de Arataca. Os Tupinambá mantinham uma relação de longa data com os assentados (ligados ao Movimento dos Trabalhadores Rurais Sem Terra - MST), havendo se somado em manifestações políticas e apoiado sua mobilização. Voltamos carregando quatro mudas de árvores, presenteadas por uma das lideranças do assentamento, para serem plantadas na TI. Em outubro do mesmo ano, representantes de diversos povos indígenas e de movimentos sociais espalharam mudas de árvores

\footnotetext{
${ }^{10}$ Observações a esse respeito já haviam sido feitas por Viegas e Paula, a partir de levantamento etnográfico em outras partes do território (BRASIL, 2009, p. 305-306).

${ }^{11}$ Sobre pés de frutas "preguiçosos" ou que se mostravam "felizes" em produzir em quantidade, ver Woortmann e Woortmann (1997, p. 171).
} 
DANIELA FERNANDES ALARCON - "Construir uma outra aldeia”...

nativas pelo conjunto de fazendas conhecido genericamente como Unacau, retomado havia cinco meses, quando aí se realizou um seminário de jovens indígenas. Importante notar que os vários povos presentes, assim como outros que ali não estavam, partilhavam a determinação dos Tupinambá da Serra do Padeiro de se mobilizar para o estabelecimento, no futuro, de uma universidade indígena (pública) nessa área em particular, o que foi lembrado durante o plantio.

Um jardim plantado na retomada Bom Jesus guardava em si reminiscências dos deslocamentos dos indígenas que viviam diante dele. Antes de se transferir à Serra do Padeiro, a família habitou em diferentes regiões da TI. Aquela era a terceira retomada em que viviam: da primeira, situada no Acuípe de Cima, levaram consigo as sementes de uma flor arroxeada; na segunda, a Futurama, viram brotar a planta, que se espalhava no jardim que cultivaram na terceira retomada. No período em que estive em campo, boa parte das flores oferecidas aos encantados e demais entidades - na casa do santo (no centro da aldeia) e nos altares domésticos, fosse em dias festivos ou como parte da devoção cotidiana - provinham de jardins como aquele, plantados geralmente pelas mulheres, em áreas retomadas.

Grandes torés costumavam acontecer diante da casa do santo. Cada retomada, contudo, possuía seu fogo: ocupada a área, ato contínuo, ele era aceso e seria reavivado de tempos em tempos, idealmente ao menos uma vez por semana. Lugares de culto específico também foram estabelecidos em algumas retomadas. Na fazenda Serra das Palmeiras, uma indígena que tinha obrigações para com lemanjá fixou um local para depositar as oferendas. Segundo ela, este ponto do terreno já adquirira características de espaço consagrado; como exemplo, ela me contou sobre um dia de chuva intensa, em que, a despeito da correnteza, as oferendas permaneceram intactas ${ }^{12}$. Quando da pesquisa em campo, ela se preparava para assentar uma imagem de lemanjá em uma grande pedra próxima a esse local, em torno da qual pretendia cultivar um jardim.

\footnotetext{
${ }^{12}$ Penso em um paralelo com o caso Xukuru de Ororubá: a Pedra D’Água, primeira área retomada pelos indígenas, que já era espaço de prática de rituais antes da expropriação, tornou-se ainda mais significativa após a recuperação, pois em sua mata forram enterrados - ou melhor, "plantados" - Francisco de Assis Araújo, o cacique Xicão, e outras lideranças também assassinadas por sua atuação na luta pela terra (SILVA, 2008, p. 270).
} 
DANIELA FERNANDES ALARCON - "Construir uma outra aldeia”...

No contexto da retomada, os Tupinambá têm de se dedicar também à implementação de estratégias de defesa do território, vigiando o desmatamento, a caça e a pesca ilegais 13. "Aqui, índios e não índios podem pescar, mas não os [não índios] de fora. Não é por pescar; é por causa da perversidade", disse-me uma indígena, aludindo às práticas de sobrepesca, entre as quais a aplicação de veneno nos rios, para "facilitar" a captura dos animais. Os indígenas utilizavam madeira para diversos fins, mas acordaram aproveitar preferencialmente a madeira caída e extrair árvores apenas em áreas de capoeira. Da mesma maneira, a maior parte deles apreciava comer caça, mas estavam buscando disciplinar a atividade, por exemplo, vedando-a em algumas áreas, destinadas à reprodução dos animais.

Segundo os indígenas, os estoques de caça estavam aumentando e as aparições dos animais tornavam-se mais frequentes. "Às vezes, a caça vem até o terreiro: tatu, paca... Outro dia, tinha um rebanho de caititu ali embaixo", disse-me uma indígena que vivia em uma área retomada, a antiga fazenda São José. Havia pouco, um indígena surpreendera-se ao entrar em uma grota e ouvir o canto de uma ave que andava sumida ("olha, ainda tem", pensou). Outro índio, por sua vez, enumerou duas dezenas de espécies de aves e macacos, dividindoas em quatro categorias: os que "ainda tem"; os que "ficaram escassos"; os que "estão recuados, mas podem voltar" e os que "não tem mais" (ou que "de primeiro, tinha"). Para os Tupinambá, essa possibilidade de retorno dependia da recuperação do território, e cada retomada vinha se constituindo como condição para tanto. Certa vez, ao voltar da mata, um indígena disse-me sorrindo: "Na Santa Rosa [retomada], as trilhas chegam a estar vivas, de tanto tatu!". Pelas ações de retomada, o território está sendo curado ${ }^{14}$.

\section{"Brotando e criando"}

"Nós somos já os brotos, que brotamos dos pés velhos, dos

\footnotetext{
${ }^{13}$ Note-se que as ameaças ao território expressam-se também na forma de projetos de infraestrutura, em consonância com o modelo de desenvolvimento hegemônico impulsionado pelos governos estadual e federal, em parceria com empresas privadas.

${ }^{14}$ Sobre esse tema, ver também Ubinger (2012, p. 103).
} 
DANIELA FERNANDES ALARCON - "Construir uma outra aldeia”...

troncos velhos. Nós estamos brotando e criando, renovando tudo de novo", disse-me um indígena que, em 2012, tinha 79 anos de idade e vivia em uma retomada. Remetendo à violência cometida contra os antepassados e a sua dispersão, ele enfatizava as tarefas da "remessa nova" (ele incluído), a quem caberia reconstruir a aldeia. Nesta seção, comentarei alguns elementos do esforço para o desenvolvimento de modos de vida próprios no marco do processo de retomada, enfatizando o papel central desempenhado pelo retorno de parentes dispersos.

A organização socioeconômica desenvolvida pelos Tupinambá no contexto de retomada não tem na fazenda sua unidade mínima. Se fosse conveniente, após a ação de recuperação territorial, duas ou mais fazendas contíguas passavam a ser geridas em conjunto. Note-se que "retomada" é um termo polissêmico: as 22 áreas recuperadas na Serra do Padeiro até maio 2012 correspondiam, naquele momento, a 14 unidades territoriais - também chamadas de retomadas -, o que se expressava na existência de 14 "coordenadores de retomada". Grosso modo, os coordenadores são compreendidos como representantes dos moradores da retomada junto ao cacique e ao conjunto dos indígenas, organizados na AITSP, e atuam também na organização do trabalho na aldeia.

Embora existissem então 14 retomadas identificáveis como tais, elas não eram compreendidas como de uso exclusivo de seus respectivos moradores. Os indígenas buscam equilibrar a fixação das famílias em áreas determinadas e seu comprometimento com a construção de uma aldeia adotando medidas destinadas a afastar o espectro da fragmentação. De um lado, disse o cacique Babau certa vez, espera-se que todos se apropriem da área que habitam, isto é, que dela cuidem e que aí vivam bem. Contudo, no caso de uma decisão coletiva, devem estar prontos para se mudar para outra área - o que, por certo, não é isento de dificuldades ${ }^{15}$. As retomadas, em síntese, devem ser entendidas como um conjunto, cuja apropriação, em última instância, é coletiva.

\footnotetext{
${ }^{15}$ Uma indígena certa vez confidenciou-me: “eu ajudo em tudo que precisar, mas não quero sair daqui [da retomada em que vivia]; eu gosto de todas as retomadas, mas gosto mais desta, estou aqui desde que ela começou".
} 
DANIELA FERNANDES ALARCON - "Construir uma outra aldeia”...

Os limites [das fazendas] terminam no dia em que a gente faz a retomada. Agora é a integração. Em cada localidade tem que morar pessoas apenas para termos o domínio das casas. E uma divisão, mas para continuarmos unidos.

Quando se considera a localização das roças e quem nelas trabalha, isso fica evidente. Diversos exemplos confirmam ser uma prática disseminada a de não se deixar barrar pelas cercas das retomadas quando se trata de plantar e colher. Nesse sentido, parece-me esclarecedor o que disse um indígena: o território, segundo ele, é conformado por "muitas roças pequenas [tanto em sítios quanto em retomadas], que, juntas, formam uma grande roça". Uma faixa de cacau no interior da Rio Cipó, por exemplo, era zelada por um morador de um sítio, posto que ficava mais próxima a sua área que à sede da retomada. Moradores de sítios mantinham também roças individuais ou familiares em retomadas. Um casal chegou a desmanchar a farinheira de seu sítio, pois Ihe resultava mais conveniente fazer farinha na retomada Futurama, vizinha - era na área da Futurama, aliás, que eles plantavam mandioca, cultivando no sítio apenas abacaxi, milho e outros pequenos plantios para consumo.

Havia diversos casos, ainda, em que moradores de uma retomada mantinham cultivos em outra. Um indígena que vivia na Bom Sossego (conhecida como "Firma" ou "Cantagalo") mantinha uma roça de abacaxi na São Roque e outra na São Jerônimo. Ele estabelecera a roça na São Roque por ser uma área contígua à Bom Sossego, próxima a sua casa; quanto à roça da São Jerônimo, começou-a em conjunto com o então coordenador desta retomada, mas acabou por assumi-la sozinho. 0 mesmo ocorria com os animais de criação, principalmente os de maior porte: os bois de diferentes donos estavam espalhados pelas retomadas. Um caso em particular dizia respeito a um indígena que morava sozinho em uma área retomada e que chegou a ter 80 galinhas poedeiras. Como elas destruíram boa parte das plantações, ele se desfez da maioria; as que sobraram, entregou à guarda de indígenas que viviam em outras retomadas e tinham melhores condições de criá-las.

A ocupação das retomadas responde a alguns critérios, dentre os quais se destacam a tentativa de manter os membros de uma família extensa na mesma área e a busca por atender a vontades pessoais ("é 
um direito dos índios"), decorrentes de afinidades com vizinhos ou com partes do território. Ambos, porém, são contrabalançados pelo que seriam necessidades mais amplas da comunidade. Nesse sentido, a distribuição de indivíduos e famílias pelas retomadas é atrelada a um esforço com vistas a equilibrar a renda monetária das famílias. Também se busca aproveitar conhecimentos territoriais que determinados indivíduos eventualmente detenham em decorrência de suas trajetórias de vida. Por exemplo, um indígena que porventura tenha sido empregado em uma fazenda agora retomada, e que conheça bem as condições das roças pode ser solicitado a viver ali, ainda que sua família extensa esteja em outra área. Assim, devido à combinação entre esses fatores (e outros ainda, mais circunstanciais), mesmo que as relações de parentesco expliquem em grande medida a distribuição dos indígenas pelas retomadas, não se pode pensar em uma correlação inequívoca entre casa e família elementar, retomada e família extensa. Pode-se "desejar" certa configuração, mas é preciso "se conformar" se as coisas não saírem como se espera, disse-me certa vez um jovem indígena.

Note-se, ainda, que rearranjos são frequentes, associados a retornos, casamentos, separações e outros acontecimentos. Tomemos o mês de junho de 2012 como exemplo. Sete novas famílias chegaram à aldeia, e foram instaladas nas retomadas Futurama e Santa Rosa. Uma família que vivia na Gruta Bahiana, e que não estava satisfeita em morar ali, foi alocada na retomada São Roque; acordou-se, contudo, que trabalhariam no cacau da São Jerônimo, arranjo considerado mais conveniente para todos. Com a saída desses moradores da Gruta Bahiana, mudou-se para lá uma família extensa (dividida em três famílias nucleares), que antes vivia no lugar conhecido como Zé Soares. Finalmente, uma indígena que vivia junto à Lagoa do Mabaço, na região litorânea, decidiu se mudar com a família para a Serra do Padeiro, pois, na velhice, queria estar perto dos parentes; passaram a viver na retomada Três Riachos, conhecida como "Ovo".

O processo de retomada, ao tempo em que se assenta em relações sociais pré-existentes, sobretudo de parentesco, também engendra novas relações. Parece-me que a convivência em uma mesma retomada tende a reforçar os laços entre vizinhos, sejam ou não parentes. Por exemplo, uma mulher com nenê novo, cujos familiares 
vivam em outra parte, pode encontrar em uma vizinha de retomada a maior fonte de apoio. O mesmo se passa com o companheirismo na resistência, com aqueles que, juntos, seguraram uma retomada. Também se desenvolvem, é claro, relações entre retomadas, formandose um circuito de reciprocidade. Presenciei moradores de uma área compartilhando produtos agrícolas (como feijão-de-corda, mangalô e maxixe) com moradores de outra; se em uma retomada não houvesse maniba, os indígenas que pretendiam botar roça iam buscá-la em outra. Os indígenas visitam-se, de uma retomada a outra, para dançar o toré, jogar dominó no fim da tarde ou comerem juntos ("Sempre um está na casa do outro, comunidade é assim, é tudo parente"). A realização de mutirões, sobre o que se comentará mais adiante, também une trabalhadores de retomadas diversas. Muitas vezes, mães, tias ou irmãs estabelecem-se temporariamente em outra retomada, para acompanhar uma parenta em seu resguardo pós-parto ${ }^{16}$. A Escola Estadual Indígena Tupinambá Serra do Padeiro (EEITSP), por sua vez, estabelecida no centro da aldeia, faz com que moradores das várias retomadas e também de sítios se encontrem com frequência, já que estudam ou trabalham ali. Finalmente, há as assembleias da associação e outras reuniões do movimento indígena, a que acorrem indígenas de várias partes.

Por outro lado, o processo de retomada pode introduzir ou acentuar tensões relativas à convivência entre indivíduos ou famílias. $O$ território é compartilhado com diversas entidades, algumas das quais deveras incômodas. Com os vizinhos humanos, a situação é análoga. Um exemplo de vizinho inoportuno é o dos "olhos maus", isto é, aquele que provoca a morte, de maneira não intencional, de tudo que admira. Contase o caso de um homem que padecia desse mal: bastou que apreciasse uma horta para que, no dia seguinte, ela estivesse destruída, tomada por um "cardume de lagartas e formigas". Quando viu o estrago, a dona dos plantios pediu ao pajé que rezasse a horta. "Painho pegou o ramo e

\footnotetext{
16 “O período do 'resguardo' deve ser entendido como um dos momentos cruciais na constituição e consolidação de laços entre casas de um mesmo lugar, através das mulheres”, assinalaram Viegas e Paula a respeito dos Tupinambá de Olivença, sem contudo se referir ao contexto de retomada (BRASIL, 2009, p. 74). Viegas tratou também da entreajuda feminina e de outras questões relacionadas à gravidez, parto e puerpério a partir de sua etnografia em outra localidade no interior da TI, Sapucaieira (VIEGAS, 2007, p. 107-112).
} 
começou a rezar. Os bichos fizeram uma filinha, um atrás do outro, e foram todos embora. Mas o estrago já estava feito", indicou uma filha de seu Lírio (Rosemiro Ferreira da Silva), pajé da Serra do Padeiro. "Se ele olhasse e admirasse um menino, dava dor nas tripas e a criança morria. É que ele tem os olhos ruins". Outras pessoas, por sua vez, acabam por matar pés de plantas de determinadas espécies ao tentar apanhar folhas, flores ou frutos ("Tem gente que tem a mão que não é própria para tirar aquela planta", explicaram-me duas indígenas em um quintal).

Em farinheiras ou ao pé do fogo, comentava-se também (com maior ou menor convicção, a depender de quem falava) sobre índios viradores de lobisomem e bruxas. Vejamos o caso destas últimas. Se uma mulher tem sete filhas, a caçula está arriscada a virar bruxa; para impedir a transformação, é preciso que a filha mais velha batize a sétima 17. Caso isso não ocorra, a bruxa, insuspeita durante o dia, vagará pelas noites, para chupar o umbigo das crianças e emaranhar o cabelo das mulheres. Há formas de evitar que ela mate os bebês (prometer-lhe uma xícara de sal, por exemplo, ou colocar uma tesoura aberta sob o travesseiro), mas nada se pode fazer em definitivo a respeito de sua presença ${ }^{18}$. O território é habitado por toda classe de seres incômodos e com eles se deve conviver. Visagens como a Pisadeira; maruins (insetos muito pequenos, de picada dolorida) e pixixicas (formiguinhas encontradas nas roças de cacau), que "mordem a gente porque não têm roça própria"; vegetais que queimam ao toque, como o temido cansanção; e gente virada em bicho.

No que diz respeito à relação com vizinhos contrários à demarcação, há desde casos de rompimento até situações mais ambíguas, como os que

\footnotetext{
${ }^{17}$ Cf. Camara Cascudo, a crença em se tornar bruxa a sétima filha teria origem europeia (CAMARA CASCUDO, 1984, p. 148). Na Serra do Padeiro, o lobisomem, analogamente à bruxa, seria o sétimo filho homem - trata-se de pequena variação do que registra o folclorista: "O lobisomem é o filho que nasceu depois de uma série de sete filhas" (CAMARA CASCUDO, 1984, p. 441). Segundo os Tupinambá, esta criatura não caminha na mata, mas sim nas estradas - ele "anda sete léguas em quadra, na noite", apoiando-se nos cotovelos, e com a cabeça entre as pernas. "Só mexe com lixo, cachorro novo, menino pagão, matadouro, só come porcaria e revira lixo". Lamber fornos de farinheiras, ainda quentes do uso, é outra de suas predileções. Para fazer com que as transformações cessem definitivamente, é preciso bater na criatura de modo que ela verta sangue. Para bater em um lobisomem, há que se usar faca curta ou bacalhau (chicote) de couro cru também curto; quando são utilizados bastões ou facões longos, o lobisomem os agarra.

${ }^{18} \mathrm{O}$ umbigo, o sal, a tesoura são todos mencionados por Camara Cascudo, que enumera copiosos "esconjuros e defesas contra a perversidade das bruxas", concluindo que estariam desaparecendo, de que tenho que discordar (CAMARA CASCUDO, 1984, p. 148).
} 
falam mal dos índios "pelas costas", mas seguem frequentando suas casas ${ }^{19}$. As dificuldades, contudo, também existem no interior da aldeia, associadas muitas vezes aos rearranjos espaciais estabelecidos no processo de retomada, bem como a discordâncias quanto a decisões coletivas. Um motivo recorrente versa sobre os sacrifícios de quem sai de sua casa - em posse própria, na cidade ou em uma parcela onde vivia "de favor" - para morar em uma retomada. Ali, tem de conviver com novos vizinhos, muitas vezes não pertencentes a seu círculo familiar, chocandose com "costumes" diferentes dos seus.

Em 2012, vigorava uma decisão coletiva segundo a qual todos os indígenas tinham assegurado o direito de se desenvolver conforme seus modos de vida particulares, desde que não violassem determinadas regras, de que se falará em seguida. Certas vezes, contudo, alguns indígenas que muito plantavam criticavam aqueles que "não trabalham", isto é, que "só caçam e pescam", que "nunca puseram roça" ou que tinham "só um cacauzinho, pouquinha mandioca". Os primeiros, contudo, também eram muitas vezes alvo de crítica dos últimos, por sua "ansiedade para o trabalho" e sua "ganância por roças"20. Há também a situação dos indígenas recém-chegados, vindos "de fora", alguns dos quais, de outras partes do território, de outras Tls ou da cidade. Todos têm de se adaptar ao "regime da aldeia", um conjunto de regras, mais ou menos formais e passíveis de alteração nas instâncias decisórias constituídas pelos indígenas, das quais a mais formal é a assembleia da associação. No primeiro semestre de 2012 , um casal indígena e seus filhos deixaram uma retomada, retornando ao sítio de sua família extensa, por não haverem observado o "regime da aldeia" (evangélicos, recusavam-se a participar do toré) ${ }^{21}$.

Em junho de 2012, uma família indígena kapinawá/kambiwá mudou-se para a Serra do Padeiro. Eram uma mulher kapinawá, seu cônjuge (sobrinho de uma índia kambiwá casada com um Tupinambá) e

\footnotetext{
${ }^{19}$ Não se deve esquecer, porém, da existência de vizinhos não índios favoráveis à demarcação.

${ }^{20}$ É claro que não existem grupos sem conflito, mesmo quando estamos diante de um território de reciprocidade (WOORTMANN, 1994, p. 266).

${ }^{21}$ A respeito das partidas por discordâncias em relação ao "regime da aldeia", um indígena comentou: os que saem "estão tão acostumados a viver nesse mundão, que quando alguém aperta os parafusos, eles acham ruim". Além disso, ele contrapunha os "mais velhos" (isto é, os indígenas que participaram desde as primeiras retomadas) aos "mais novos", argumentando que os primeiros tinham mais condições de observar o presente em perspectiva, posto que conheciam a história da luta. É claro que os pontos de vista dos que saíam e dos "mais novos" eram outros.
} 
DANIELA FERNANDES ALARCON - "Construir uma outra aldeia”...

filhos. Na assembleia realizada nesse mês, eles receberam as boasvindas e ouviram uma explicação sobre como funcionava a aldeia. As regras que Ihes foram apresentadas então podem ser lidas na ata da assembleia: "não ao alcoolismo, crianças na escola, não ao espancamento do marido ou mulher ou ao maltrato de crianças". Outras regras vigoravam também, determinando, por exemplo, a participação dos indígenas na realização de retomadas e nos rituais. Estava interditada a realização de novos casamentos com não índios - melhor dito, tais casamentos até poderiam ser realizados, mas os casais não eram autorizados a viver em áreas retomadas -, ao passo que eram aceitos aqueles pré-existentes. Conforme Macedo, "Quanto a isso os Tupinambá costumam dizer que 'quem está dentro fica, mas quem está fora não entra mais'” (MACEDO, 2007, p. 192). Como se vê, o processo de retomada e a demarcação da $\mathrm{TI}$ transformaram as prescrições relativas ao casamento. Nesse sentido, como indica Woortmann, é fundamental considerar o parentesco de forma diacrônica, atentando para a centralidade da terra (WOORTMANN, 1994, p. 257-283). Ainda nesse âmbito, Macedo comenta a determinação dos indígenas de "fazer a aldeia crescer", incentivando as mulheres a engravidar (MACEDO, 2007, p. 96), o que também observei em campo.

Note-se que, além de conhecer as regras em vigor na aldeia, os indígenas recém-chegados devem ainda se apropriar da história de resistência que se vem desenrolando ali. Em 19 de abril de 2012, durante uma reunião ampla, o cacique Babau repassou, em grandes linhas, a história do processo de recuperação territorial, dirigindo-se especialmente aos que "vieram depois". Dias depois, ao preparar uma ocupação da Secretaria de Saúde Indígenas do Ministério da Saúde (Sesai/MS), em Salvador, para exigir o cumprimento de um conjunto de reivindicações, o cacique preocupou-se em levar "gente que não tinha experiência de movimento" - jovens, recém-chegados ou pessoas que, por diversas razões, nunca haviam participado de ações como aquela. Alguns indígenas manifestaram-me preocupações em torno da formação política de crianças e jovens, que nasceram ou cresceram já em retomadas, em condições muito mais confortáveis que as vividas por seus pais. Certo dia, uma senhora comia laranja com farinha, no terreiro de sua casa, ensinando a dois netos pequenos como fazê-lo. Alguém, 
DANIELA FERNANDES ALARCON - "Construir uma outra aldeia”...

de passagem, repreendeu-a: "Para que está comendo isso? Nós não passamos mais fome, isso é do tempo em que não tinha carne". Ao que ela respondeu, muito séria: "Acabou, mas precisamos lembrar como era".

Nesse quadro, a chegada de determinados encantados, em lugar de outros, guarda íntima relação com as premências vividas pelos indígenas. Durante um concorrido toré realizado em 13 de junho de 2012, noite de Santo Antonio, o pajé incorporou o caboclo Marombá. Era a segunda vez que o encantado se apresentava na aldeia - seu Lírio já o recebera semanas antes, no toré em comemoração à decisão do Supremo Tribunal Federal (STF) na ação de nulidade dos títulos de propriedade emitidos sobre a Reserva Indígena (RI) Caramuru-Catarina Paraguaçu. Nas duas ocasiões, os cantos entoados por Marombá versavam sobre elementos do que deveria ser o cotidiano dos indígenas. $\mathrm{Na}$ primeira aparição, Marombá disse que iria "cantar para as pessoas ficarem sabendo das coisas". Mais tarde, complementou: "o caboclo Marombá vai ajudar vocês a viver, a levantar a aldeia". O encantado ensinava os indígenas a pescar com jereré; explicava a utilidade de artefatos como o samburá; indicava como utilizar a folha da patioba e como produzir remédios. Os cantos eram entremeados com explicações mais pormenorizadas e, de quando em quando, o encantado interpelava algum dos presentes: “aprendeu?". À performance de Marombá, seguiuse, como de praxe, o comentário do cacique Babau:

Marombá é um caboclo mais conversador, está aqui para nos ensinar a viver bem. Antes, chegavam caboclos que falam menos, como Tupinambá, porque a situação era outra, e eles precisavam nos proteger nos embates. Marombá está aqui para nos ensinar a viver em comunidade.

Em diversas ocasiões ouvi indígenas dizendo que era preciso "aprender a viver" no território retomado - e, note-se, viver em conformidade com a "cultura" 22 . E, como ficou claro, os encantados "ensinavam". Uma indígena certa vez alertou os demais para a dimensão

\footnotetext{
${ }^{22}$ Sonja Mara Mota Ferreira, em sua dissertação de mestrado acerca da implementação da EEITSP, discorre sobre a noção de "aprender a ser índio Tupinambá". Para a pesquisadora, a escola é um dos âmbitos desse aprendizado, que, contudo, realiza-se "no espaço mais amplo da luta política", inclusive nas retomadas (FERREIRA, 2011, p. 142-143).
} 
da cultura como garantidora da continuidade do povo e de sua posse territorial: "Nós só estamos vivendo aqui até hoje por causa da cultura que deus deixou para nós. Ou cuida da cultura, do ritual, ou se acaba. E quando se acabar, não acaba um [índio] só, não". A ação de recuperar uma fazenda, nesse sentido, poderia até ser a culminância de um processo de luta, mas inaugurava uma etapa ainda mais difícil, que demandava esforços concertados para a manutenção de modos de vida próprios $^{23}$. Nesse quadro, avaliava o cacique Babau, as retomadas seriam "a base de sustentação da vida em comunidade" ou, ainda, "um laboratório, onde ocorre o resgate do 'ser índio', pelo qual passam vários povos indígenas na Bahia".

Se a escuta dos conselhos dos encantados é um importante meio de aprendizagem sobre como ser índio, também o é a rememoração atenta de experiências pessoais diretas, bem como sua transmissão para os mais jovens. Algumas vezes, ouvi dos Tupinambá que a transmissão dos saberes operava principalmente pelo sangue; observei, contudo, que muito se aprendia no convívio. Penso, por exemplo, no caso de um jovem, filho de não índios, que vivia na aldeia desde pequeno, pois seu pai se casara com uma indígena. Sem ser Tupinambá "de sangue", ele aprendera com o pajé a fazer uma ampla variedade de objetos, tornando-se um dos mais hábeis artesãos em atividade durante o período que passei em campo.

No marco do processo de retomada, assinalavam alguns indígenas, seria desejável recuperar hábitos que se praticava até recentemente e que haviam sido abandonados - como, por exemplo, a elaboração de flautas de taboca. Moradores de distintas partes do território também teriam saberes a trocar. Um indígena que vivia junto ao rio de Una falou-me, certa vez, das diferenças no cotidiano dos indígenas "lá de cima, do alto" (dos pés de serra) e os "da beirada do rio". Como esse senhor fosse versado nas artes da pesca, uma

\footnotetext{
${ }^{23}$ Os Tupinambá da Serra do Padeiro costumavam criticar os desacordos em torno da apropriação das áreas retomadas e as disputas entre caciques que, segundo eles, ocorreriam em outras áreas da TI. Brasileiro (1996) e Tófoli (2010), referindo-se respectivamente às retomadas entre os Kiriri, na Bahia, e entre os Tapeba, no Ceará, comentam a relação entre retomadas e tensões internas. "Em alguns casos, ocorre que as retomadas representam momentos de grande coesão dos envolvidos. E, uma vez consolidada a ação, essa coesão se transfigura em um processo de disputas e divergências internas em relação a quem deveria ocupar ou utilizar a área e quais os usos a ela atribuídos" (TÓFOLI, 2010, p. 53). Alternativamente, observa Tófoli, as retomadas podem ser motivadas por disputas internas.
} 
DANIELA FERNANDES ALARCON - "Construir uma outra aldeia”...

professora indígena the pedira para que ensinasse as crianças a elaborar redes e munzuás.

Com o passar do tempo, mesmo que à sombra da violência de capangas contratados por fazendeiros, os Tupinambá vêm buscando estabelecer seu cotidiano nas retomadas. Em 2012, indígenas que viviam na Futurosa finalmente se sentiram seguros para retomar uma prática intimamente ligada à história de sua família, e que haviam abandonado, em decorrência da repressão aos Tupinambá. Pela primeira vez, a bandeira do Divino Espírito Santo foi recebida em uma área retomada na Serra do Padeiro. Anualmente, duas bandeiras vermelhas com a imagem de uma pomba branca ao centro percorrem Olivença e a zona rural de Ilhéus e municípios vizinhos, durante semanas, arrecadando esmolas para a realização da festa do Divino, na sede do antigo aldeamento ${ }^{24}$. As bandeiras, conduzidas por romeiros a pé, fazem percursos diferentes, encontrando-se no dia da festa, defronte à igreja de Nossa Senhora da Escada.

Costa elaborou uma hipótese interessante, que registrei durante a defesa de sua dissertação de mestrado (COSTA, 2013): "com a festa, eles [os indígenas] já tinham identificado a extensão da terra [TI] antes do estudo antropológico". Isso porque, como ele verificou, os devotos da bandeira percorriam a cada ano as comunidades que posteriormente seriam identificadas como parte da TI. Como se vê, estamos diante de uma demarcação simbólica do território, que, a um só tempo, precede e extrapola o reconhecimento estatal ${ }^{25}$.

Durante a peregrinação, os devotos aproximam-se das casas cantando e batendo caixas. Nos locais onde a bandeira "dorme", compõem-se altares domésticos, diante dos quais os presentes rezam, conduzidos pelos devotos; em seguida, é servida uma ceia. Até 2012, a bandeira circulava por áreas na Serra do Padeiro - pernoitava, por exemplo, na casa de indígenas no lugar Zé Soares -, mas os romeiros adentravam apenas em sítios em posse dos índios, nunca em retomadas. Antigamente, o bisavô materno da indígena que chamarei de Rosa recebia a bandeira em sua casa, no Santana; a família de seu cônjuge, a

\footnotetext{
${ }^{24}$ A festa do Divino é móvel, realizando-se no dia de Pentecostes, 50 dias após o domingo de Páscoa. Em 2012, as bandeiras chegaram a Olivença em 26 de maio e a missa foi realizada no dia seguinte.

${ }^{25}$ Viegas e Paula referiram-se à festa, mas apenas enfatizando seu papel no sentido de unir os índios que habitavam diversas localidades do território (BRASIL, 2009, p. 269, 491-492).
} 
que me referirei como João, também, e ambos se tornaram "devotos da bandeira". Rosa lembra:

Quando eu era menina, desse tamainho, eu ia para a casa do meu bisavô [por ocasião da bandeira]. Conheci [João] no dia da bandeira. Nós ficamos namorando, dois anos, e eu terminei, porque não queria casar nova. Quando foi no outro ano, na bandeira, a gente começou a namorar de novo. Tudo no tempo da bandeira.

Depois de casados, receberam a bandeira em sua casa (em posse própria), sem falhar, por 31 anos. Contudo, quando se mudaram para a retomada Futurosa, em 2008, ano de intensos ataques perpetrados pela Polícia Federal (PF) contra os indígenas, temeram pela segurança de devotos e demais convidados (o acontecimento atraía muita gente) e suspenderam a passagem da bandeira por sua casa. Em maio de 2012, a bandeira voltou, passando como sempre pelo lugar Zé Soares, mas também pelo centro da aldeia, pela retomada Futurama e por outras partes do território, sendo saudada, na última noite, com um grande toré. $O$ fortalecimento de "costumes" como a bandeira, enfatizavam os Tupinambá, assim como o gozo da "boa vida", a convivência, a troca de saberes e de histórias, e o companheirismo na resistência vinham construindo a aldeia. Nesse quadro, as retomadas de terras cumpririam um importante papel, no sentido de uni-los em torno de uma obra e de um projeto coletivos ("Aqui, todo mundo fez a retomada junto; as retomadas, foi todo mundo que fez").

\section{Trabalho e autonomia}

"A roça aqui [na fazenda São José, retomada] não dava nada. Aí painho rezou os aceiros [limites] da roça e acabaram as pragas", contou-me uma filha de seu Lírio, o pajé da Serra do Padeiro26. O caso da São José, retomada em 2007, ilustra que procedimentos os indígenas têm de realizar para efetivar a retomada das áreas outrora em posse dos não índios, para além do ato de entrada na fazenda. Casas têm de ser

\footnotetext{
${ }^{26}$ Os aceiros são "faixas de segurança para impedir a propagação do fogo [da queima e da goivara, como é referida a coivara na Serra do Padeiro] para além do espaço destinado ao roçado" (WOORTMANN e WOORTMANN, 1997, p. 55).
} 
rezadas, para se tornarem novamente habitáveis - batendo folhas de cuarana, defumando as áreas com capim de aruanda e cantando, os indígenas tratam de "mandar embora o que havia de mau". Da mesma maneira, para que se restabelecesse o potencial produtivo dessas áreas, as roças tiveram de ser rezadas. "Aqui, é normal rezar roça. Você vai de manhã e reza em três cantos, deixando um livre para ser a porta de saída. Reza com galhos e matos colhidos lá mesmo", explicou-me uma indígena ${ }^{27}$. No caso da São José, disse, os efeitos eram perceptíveis quando se considerava a evolução da produção de cacau:

Essa área dava mil arrobas de cacau, com o primeiro dono. Com o segundo, não dava nada - era um calumbi desse tamanho. O cacau ia virar rama, antes de retomar, de tão fininho que estava. Quando retomamos, no primeiro ano, deu só 60 arrobas. Depois que rezou a roça, produziu duzentas.

Grupos e indivíduos que se opõem à demarcação da TI insistiam que ela provocará - já está provocando - a derrocada econômica da região. Segundo a análise dos Tupinambá, contudo, ocorre o inverso: os indígenas, retomando áreas e nelas produzindo, dinamizam uma economia estagnada. Uma dimensão das retomadas, enfatizam, consiste na garantia de "ter terra para produzir", o que se traduz na possibilidade de continuidade dos modos de vida por eles historicamente engendrados. Nesse sentido, a construção de estratégias econômicas que passam, sobretudo, pela organização do trabalho - é um componente central do processo de retomada, como se buscará indicar a seguir. Apresentar-se como um grupo muito organizado, com capacidade de produzir em quantidades suficientes para garantir sua segurança alimentar e gerar renda, é um movimento recorrente no discurso dos Tupinambá quando se trata de demarcar os acertos de sua luta. De forma dialética, sua capacidade produtiva é por eles entendida como uma condição que os fortalece em sua mobilização política. Nesse sentido, estou de acordo com Ubinger, quando ela apresenta uma definição ampla de "roça": "A roça pode ser entendida como uma maneira de viver, uma forma de estabelecer autonomia" (UBINGER,

\footnotetext{
${ }^{27}$ Os sitiantes sergipanos etnografados por E. e K. Woortmann também tinham por hábito rezar roças, ainda que os procedimentos adotados ali fossem diferentes daqueles vigentes na Serra do Padeiro (WOORTMANN e WOORTMANN, 1997, p. 61).
} 
DANIELA FERNANDES ALARCON - "Construir uma outra aldeia”...

2012 , p. 17). Penso que, sobretudo, a produção é compreendida pelos Tupinambá como atrelada às suas perspectivas de "bem viver".

As destinações de cada retomada, do ponto de vista econômico, têm de ver com as características identificadas pelos Tupinambá. Certas áreas, como a Santa Rosa, são conhecidas por apresentar solos mais férteis, tornando-se mais propícias para cultivo e podendo, assim, abrigar mais famílias ${ }^{28}$. Em outras, como a São Roque e a São Jerônimo, há bons pastos, sendo mantidos aí bois e ovelhas. Na primeira área retomada, a Bagaço Grosso, inicialmente viveram algumas famílias. Mas, quando outras fazendas foram recuperadas, os indígenas decidiram mantê-la desabitada, apenas como área de preservação ambiental, já que aí se localizam algumas nascentes. Tiveram, contudo, de abrir uma exceção, ainda que a contragosto, para um indígena idoso. Ainda que os parentes quisessemno perto, preocupados por sua idade, ele passou por diferentes áreas recuperadas, sem se adaptar, e terminou por se instalar, sozinho, na Bagaço Grosso (“Índio mesmo mora no mato, debaixo de uma palha grossa, uma moita, um trem. Índio vai andar no meio daquele monte de gente? Não").

Os cultivos perenes encontrados nas fazendas quando das ações de retomada têm sido mantidos pelos Tupinambá, que buscam recuperá-los e, caso convenha, ampliá-los. Trata-se, principalmente, de roças de cacau e seringueiras - estas últimas, introduzidas em consórcio com as primeiras, para sombreamento e aproveitamento do látex ${ }^{29}$. São cultivos de finalidade comercial, sendo o cacau em alguma medida aproveitado pelos Tupinambá para autoconsumo: eventualmente, comem o fruto, e o mel (seiva) que dele se extrai é bastante apreciado, puro ou no preparo de licor e geleia, podendo ainda, depois de azedar, converter-se em vinagre, usado em conservas de pimenta ${ }^{30}$. Desde as

\footnotetext{
${ }^{28}$ Os indígenas dispõem de conhecimentos para verificar a fertilidade do solo. A existência de árvores como o pau-alho, por exemplo, indica que, naquele local, o solo é fértil.

${ }^{29}$ Nas últimas décadas do século XX, a Ceplac incentivou o plantio de pés de seringa na região cacaueira; a propaganda da sericultura, contudo, vinha de longa data. Silva Campos registra a distribuição aos fazendeiros de sementes e mudas já em 1926 (SILVA CAMPOS, 2006, p. 611-612).

${ }^{30} \mathrm{O}$ mel de cacau pode ser extraído de duas maneiras: com o auxílio de uma prensa mecânica ou em uma "cama de cacau". A cama é elaborada na própria roça ou em suas imediações, aproveitando-se um desnível no terreno, não muito acentuado. Os indígenas dispõem dois troncos de bananeira, de modo a formar uma letra $v$, com o vértice localizado na parte inferior do terreno. Em seguida, forram o espaço entre os troncos com folhas de bananeira e, sobre elas, depositam as amêndoas do cacau recém-quebrado, cobrindo-as com outra camada de folhas. $\mathrm{O}$ sumo que envolve as amêndoas, extraído pela ação da gravidade, escorrerá para um recipiente depositado junto à intersecção dos troncos, de onde será coletado.
} 
primeiras retomadas, os indígenas discutem formas de gestão dessas roças e de apropriação da renda delas resultante; vejamos que modelo vigorava quando da pesquisa em campo.

Diferente do que se passava com o cacau e a seringa que porventura existissem em sítios mantidos pelos indígenas, cacaueiros e seringais em áreas retomadas eram sempre apropriados coletivamente. Cada retomada, como se indicou, tinha um coordenador. Suas principais atribuições eram mediar a resolução de conflitos e, principalmente, organizar o trabalho no âmbito da retomada, garantindo que as roças fossem zeladas, que se realizassem os consertos e melhorias necessários, e que as áreas de uso comum fossem mantidas limpas e organizadas. Aos moradores de cada área era facultado decidir se participariam ou não do trabalho nas roças de cacau e na seringa podiam, como se indicará, concentrar-se apenas em roças familiares ou individuais, de mandioca, banana e outras culturas. Note-se que, como nem todos os indígenas sabiam "cortar seringa", isto é, extrair o látex, apenas alguns desempenhavam essa atividade - havia indígenas que se dedicavam somente à seringa, ao passo que outros atuavam na seringa e no cacau. O valor obtido com a venda das amêndoas de cacau e do látex produzidos nas retomadas era distribuído igualmente entre os que haviam trabalhado ao longo de cada processo ${ }^{31}$. Nesse sentido, o potencial de geração de renda de cada retomada era um dos fatores que determinava a distribuição dos indígenas no território. Como se indicou, o desejo de um indivíduo ou de uma família de se transferir para outra área podia ser atendido. Antes que a alteração fosse aprovada, contudo, tinham de ser avaliados os impactos sobre a renda das famílias que viviam na área destino ("tem que ver se é sustentável").

A partir de 2009, 30\% do valor da venda do cacau e do látex de áreas retomadas passaram a ser destinados à AITSP. Parte desse valor era utilizada na manutenção da associação e em gastos do movimento indígena, e parte era reinvestida(ASSOCIAÇÃO DOS ÍNDIOS TUPINAMBÁ DA SERRA DO PADEIRO, 2009). Em fevereiro de 2012, foi estabelecida

\footnotetext{
${ }^{31} \mathrm{Na}$ entressafra, os cacaueiros são zelados: podados, desbrotados e coroados (as folhas caídas são amontoadas junto aos pés). Na safra, deve-se colher e bandeirar (apanhar o cacau derrubado no chão), quebrar os frutos, extraindo as amêndoas, secá-las e pisá-las. O baixo preço pago pelos atravessadores (dos municípios de Buerarema e São José da Vitória) fazia com que os Tupinambá pulassem a etapa de fermentação, que aumentaria a qualidade do produto.
} 
outra forma de contribuição obrigatória, destinada a indígenas assalariados, com valores progressivos. Essas duas modalidades de contribuição (o percentual sobre as roças de cacau e seringa, e as taxas pagas pelos assalariados) substituíam a contribuição estabelecida no estatuto da AITSP, que previa o pagamento mensal, por todos os filiados, de 1\% do salário mínimo.

No que diz respeito ao reinvestimento dos recursos nas roças, eram priorizadas as áreas que atravessassem maiores dificuldades econômicas, como evidenciam as prestações de contas periódicas da associação. Note-se que algumas retomadas produziam mais que outras, por diferentes motivos - as condições em que se encontravam as roças quando as áreas foram recuperadas, a extensão dos plantios, a idade dos cacaueiros, o número de famílias trabalhando. Com a medida, os indígenas tentavam equacionar essas distorções. O fato de alguns mostrarem-se refratários à política suscitava acusações de "individualismo" - conforme seus críticos, estariam a um passo de se tornar "fazendeiros".

Após acordarem a redistribuição da renda, os Tupinambá implementaram outra medida visando minar o "individualismo" e a tendência de isolamento dos indígenas nas áreas onde viviam: a realização de mutirões de trabalho semanais, cada vez em uma retomada. Diferentes formas de trabalho foram testadas na aldeia desde que teve início o processo de retomada. Antes da implementação da contribuição obrigatória de $30 \%$, por exemplo, os recursos da associação provinham de uma roça específica, trabalhada coletivamente. Porém, cuidar da roça da associação, do cacau e da seringa das retomadas, e ainda de roças individuais e familiares tomava muito tempo, o que levou os indígenas a tentar outro modelo. Em janeiro de 2012, acompanhei pela primeira vez um mutirão - também referido como "comunitário" -, realizado na antiga fazenda Santa Helena, com a participação de 36 homens.

A programação dos mutirões, isto é, a escolha das áreas em que trabalhariam a cada semana, fora previamente acordada, em uma assembleia da AITSP. Já a escolha da atividade a ser desempenhada ficava a cargo do coordenador de cada retomada. Durante o mutirão na Santa Helena, os indígenas realizaram a "desbrota", isto é, a poda 
DANIELA FERNANDES ALARCON - "Construir uma outra aldeia”...

superficial dos cacaueiros, retirando os "brotos ladrões" (galhos laterais, que retardam o desenvolvimento dos frutos). Naquele dia, um indígena explicou-me que apoiava a realização dos mutirões por entender que, com isso, os moradores de uma área passariam a saber o que ocorria nas outras, fortalecendo-se o comprometimento de todos com a construção da aldeia. Ademais, assinalou, ao saber que os indígenas trabalhavam juntos, os indivíduos contrários à demarcação veriam que estavam "fortes e unidos". É claro, porém, que nem todos eram entusiastas da medida, ainda que não necessariamente questionassemna publicamente; de tempos em tempos, o problema do "corpo mole" no mutirão fazia sua aparição na pauta da assembleia.

Além do "comunitário", ocorriam também acordos de trabalho localizados, que poderiam ser pontuais ou duradouros. Quando havia necessidade de empreender uma tarefa excepcional, que demandasse grande quantidade de trabalho, era comum que fossem firmados acordos envolvendo indígenas de diferentes retomadas. Em outros casos, coordenadores de retomadas vizinhas estabeleciam parcerias por tempo indeterminado, para potencializar a mão de obra disponível em cada área. Em maio de 2012, por exemplo, vigorava um acordo de troca de tempo entre os coordenadores de dois conjuntos de retomada nos seguintes moldes: ao longo da semana, os indígenas atuavam cada qual em sua respectiva retomada; às sextas-feiras, porém, trabalhavam juntos, alternando as áreas semanalmente ${ }^{32}$.

Um indígena, então coordenador de retomada, comentou-me em diferentes ocasiões as dificuldades de se estabelecer relações de trabalho que não reproduzissem "o modo de trabalho como é lá fora", considerando-se que muitos indígenas aprenderam a trabalhar conforme as regras dos não índios. "Retomada não é para ninguém enricar nem para viver de cacau", dizia outra indígena - entenda-se "viver de cacau" por reproduzir o modelo de exploração capitalista que vigorava na região havia décadas. Nesse sentido, agir como se as retomadas fossem apenas espaços de morada ou fator de produção, em lugar de se engajar em um processo mais amplo - isto é, na construção

\footnotetext{
${ }^{32} \mathrm{Um}$ deles coordenava conjuntamente as antigas fazendas Santa Helena, Três Riachos (conhecida como "Ovo"), Bom Sossego ("Do padre") e Vencedora; o outro, as fazendas Boa Sorte, Triunfo e Bom Sossego ("Da igreja"). Na época, em cada conjunto de áreas, havia três indígenas trabalhando no cacau.
} 
DANIELA FERNANDES ALARCON - "Construir uma outra aldeia”...

de perspectivas de vida autônoma, baseadas em outras formas de organização coletiva, de modo a realizar as retomadas plenamente - é um comportamento que ouvi ser sancionado algumas vezes. Contaramme, por exemplo, o caso de dois homens que viviam em uma retomada mas seguiam trabalhando para fazendeiros, sem participar das atividades coletivas. Instados a mudar seu modo de agir - "isso aqui é hotel?", uma liderança ter-lhes-ia dito à época -, acabaram por sair da retomada e deixar o movimento. Em algumas situações, ouvi os indígenas expressarem desaprovação em relação a um parente "que prefere trabalhar para os brancos que plantar para si mesmo".

Um documento da associação datado de abril de 2008 indica que as dificuldades enfrentadas nas retomadas em seus primeiros anos, até que as roças começassem a produzir, fazia com que alguns indígenas estivessem, à época, "trabalhando semanalmente para alguém [não índio] para fazer sua feira". Com isso, tinham pouco tempo para cuidar das roças em retomadas e menos ainda para plantar roças próprias, minando as possibilidades de construção de vida autônoma33. "Não queremos parentes dependendo do outro [do não índio] para se alimentar", assinalava o documento; por isso, solicitavam ao governo do estado a concessão emergencial de algumas cestas básicas. Desde as primeiras retomadas, o fornecimento de materiais de construção (telhas e pregos) aos recém-chegados - comprados pela associação com a renda obtida de farinhadas e da venda do cacau - e a distribuição de cestas básicas aos indígenas que ainda estavam "se equilibrando" eram adotados como estratégia do movimento ${ }^{34}$. Em 2012, já nenhum indígena morador das retomadas da Serra do Padeiro trabalhava fora da aldeia: alguns exerciam funções assalariadas relacionadas à educação escolar indígena e à saúde, e a maioria (incluindo alguns dos assalariados) atuava na agricultura ${ }^{35}$.

Com o tempo, paralelamente ao manejo dos cultivos préexistentes nas fazendas, os indígenas passaram a ocupar as áreas retomadas com uma ampla variedade de cultivos de ciclo curto, em regime itinerante de roçados (corte e queima). Dessas roças, extraíam

\footnotetext{
${ }^{33}$ Sobre a noção de trabalho para o outro como sujeição ou "cativeiro", em oposição ao trabalho "livre", ver Woortmann (1988, p. 31-32).

${ }^{34}$ A esse respeito, ver também Couto (2008, p. 96).

35 A exceção, mas apenas em certo sentido, eram os índios contratados como motoristas pela empresa responsável pelo transporte escolar indígena.
} 
DANIELA FERNANDES ALARCON - "Construir uma outra aldeia”...

boa parte dos itens de sua dieta e da alimentação dos animais de criação, comercializando o excedente. Geralmente, tratava-se de roças individuais ou familiares. Contudo, relações de afinidade ("nós três gostamos de trabalhar juntas") podiam dar origem a roças de ciclo curto coletivas. Objetivos em comum, também. Todos os anos, alguns indígenas plantavam uma roça em conjunto para, com a renda obtida a partir dela, viajarem em romaria a Bom Jesus da Lapa, no oeste do estado. Roças eram estabelecidas coletivamente também para financiar atividades do movimento indígena, como a realização de um seminário de jovens ou a ida de representantes da Serra do Padeiro a um encontro de mulheres.

Plantava-se, sobretudo, mandioca e banana, mas também abacaxi, abóbora, andu, batata, cana, feijão, inhame, jiló, mangalô, maxixe, melancia, milho e quiabo. Só no que diz respeito à banana, eram ao menos 17 variedades: banana-caipira, banana-cessa, bananad'água (também referida como caturrão e nanica), banana-da-terra, banana-prata, banana-prata-branca, banana-roxa, banana-roxabranca, banana-roxa-crioula, china, maranhão, pacovã, pioneira, pontaparada, sete-pencas, terrinha e três-pencas. Entre as variedades de mandioca - aleixo, branquinha, caravela, cria-menino, joão-deitado, milagrosa e riqueza (também chamada riquezinha) -, uma das mais apreciadas era esta última, de que se produziria a farinha de melhor qualidade. Os indígenas mantinham ainda, como já se indicou, hortas e pomares, destinados principalmente ao autoconsumo. Obtinham, assim, diversas hortaliças, leguminosas, condimentos e frutas, como abacate, acerola, cupuaçu, coco, goiaba, graviola, jaca, jambo, manga, mangustão e pinha, entre outras. Havia, também, pés de frutas (como tangerina, limão-balão, lima e jenipapo) dispersos nas matas de cacau, um hábito antigo, mantido a despeito dos esforços uniformizadores da Comissão Executiva do Plano da Lavoura Cacaueira (Ceplac).

Um conjunto de regras, transmitidas oralmente, rege as práticas agrícolas dos Tupinambá da Serra do Padeiro ${ }^{36}$. Cultivos perenes são manejados conforme seus ciclos próprios; no que diz respeito a cultivos

\footnotetext{
${ }^{36}$ Ao analisar os modos de trabalho de sitiantes no Sergipe, E. e K. Woortmann observaram que as etapas da produção agrícola nunca se compunham exclusivamente de trabalho braçal: eram "todas informadas por um saber acumulado e em constante processo de atualização" (WOORTMANN e WOORTMANN, 1997, p. 36). O mesmo se passa na Serra do Padeiro.
} 
de ciclo curto, contudo, as decisões sobre quando plantar são tomadas com base na observação das fases da lua e em um calendário de dias santos $^{37}$. O sol apenas aquece a Terra - explicou-me um indígena -, o que de fato regula a vida no planeta é a lua. As pragas que atacam certos vegetais são guiadas até as plantas pela luz da lua; por isso, tais cultivos devem ser feitos sempre "no turvo", isto é, no período do dia em que a lua não está visível. Na lua crescente, por exemplo, essas espécies só podem ser plantadas pela manhã, já que a lua nasce ao meio-dia. Na lua cheia, não serão plantadas. Para os Tupinambá, a influência da lua recai sobre tudo que é vivo. A andada do caranguejo ocorre sempre a partir de fevereiro, na passagem da lua minguante para a nova. Se um coco tiver pouca água, dir-se-á que "foi secado pela lua". "É porque o coco botou no tempo errado - que nem a mulher que pare no tempo errado, e a criança nasce toda esquisita" 38 .

Note-se, contudo, que mesmo se os indígenas observarem as regras de plantio, os cultivos por vezes terminam prejudicados por fenômenos que escapam ao controle. Uma melancia, por exemplo, ficará "piúca" (isto é, farelenta) caso uma forte trovoada ocorra quando ela ainda estiver no pé ("a terra estremece e ela fica piúca"). O mesmo ocorre com a abóbora, que se torna aguada e ruim ao paladar. Sol em excesso também tem consequências negativas sobre algumas culturas. "O sol é bom quando a banana está engrossando, quando está crescendo o fruto. Mas, quando o pé ainda está crescendo, é ruim. O pé sofre". A falta de chuvas no primeiro semestre de 2012 fez com que boa parte do milho plantado no dia de São José se perdesse ou nascesse mirrado. Também já comentei os estragos que podem ser feitos a uma roça ou a uma horta por alguém de "olhos maus".

Outra atividade desenvolvida em sítios e áreas retomadas era a

\footnotetext{
${ }^{37}$ Carvalho et al. indicam algumas relações entre cultivos e dias santos na Serra do Padeiro: a melancia, por exemplo, deveria ser plantada no máximo até o dia de Santa Luzia (13 de dezembro), para ser colhida antes da quaresma, período em que as lavouras sofreriam com o ataque de pragas (CARVALHO et al., 2010, p. 182). Sobre as relações entre o ciclo lunar e a agricultura para dois grupos camponeses, que guardam pontos em comum com o que observei na Serra do Padeiro, ver Woortmann e Woortmann (1997, p. 98-104).

38 "Para os Tupinambá da Serra [do Padeiro] a lua cheia representa força, quando o neném é gerado ou nasce sob a influência dela, significa que ele será forte. Nascer na lua nova também é sinal de fortaleza. Mas se ocorre um parto ou fecundação na regência da lua minguante, a criança provavelmente vai ser "fraquinha"' (MACEDO, 2007, p. 108). Macedo indica ainda que as indígenas explicavam a menstruação (para as mulheres mais velhas, "misturação") como também regida pelo ciclo lunar (MACEDO, 2007, p. 92).
} 
criação de animais - como galinhas, patos, porcos, ovelhas e bois -, que também se destinavam ao autoconsumo e à venda. Por vezes, indicaramme alguns indígenas, quando o preço de venda não condizia com os gastos dispendidos na criação dos animais, resultava mais vantajoso apenas consumi-los. Em que pese essas situações, a atividade era reconhecida por contribuir para a segurança monetária dos indígenas: bovinos e suínos funcionavam como reserva de valor, atendendo a emergências, pois podem ser vendidos facilmente em curto prazo. No contexto de repressão às retomadas, os bois foram providenciais. Os indígenas tinham por hábito comprar bezerros no sertão e deixá-los engordando, para consumo próprio - consideravam a qualidade dessa carne muito superior àquela comprada "na rua". Quando, em 2010, diversas lideranças foram presas e a aldeia estava sob ataque, venderam todas as cabeças, para pagar os honorários de um advogado e outras despesas. Em 2012, a associação dispunha de poucos bois, apenas, e de algumas ovelhas.

De maneira análoga eram entendidas as roças de mandioca, já que, em face de uma despesa inesperada, os indígenas poderiam recorrer a elas. Ainda que o melhor seja esperar um ano de cultivo para arrancar os tubérculos, no caso de algumas variedades, a partir de dez meses já é possível fazê-lo; com mais um ou dois dias completa-se o processo de elaboração da farinha, que se detalhará mais adiante, e é então possível vendê-la. Estabelecer roças para as crianças também era um hábito difundido - uma avó poderia, por exemplo, plantar tantas tarefas de mandioca, reservando-as como poupança para um neto. O papel da mandioca como o cultivo indígena por excelência era constantemente enfatizado pelos Tupinambá, em oposição, sobretudo, ao cacau. Os indígenas mais velhos, principalmente, costumavam alertar os mais jovens em relação ao perigo de se deixarem seduzir pelo cacau. $O$ que fariam no "paradeiro", isto é, na entressafra? ${ }^{39} \mathrm{E}$ se a colheita não fosse boa, como ocorre muitas vezes, devido à vassoura-de-bruxa e ao "mela" (doença causada por um fungo, também conhecida como podridão-parda)? Não é que devessem deixar de plantar cacau, diziam, mas cultivá-lo

\footnotetext{
${ }^{39}$ Ainda que os cacaueiros com modificação genética introduzidos na região frutifiquem o ano todo, na época correspondente ao "paradeiro", as árvores produzem pouco. Em referência ao ato de apanhar esse "cacauzinho", diz-se "bongar". Do quimbundo, significa catar, procurar (LOPES, 2003, p. 45).
} 
DANIELA FERNANDES ALARCON - "Construir uma outra aldeia”...

exclusivamente seria um erro. O melhor seria diversificar a produção e ser estratégico: se o preço de compra da farinha de mandioca, por exemplo, estivesse baixo, "aí que era hora de zelar as roças de mandioca, porque quando o preço da farinha subisse, ninguém teria para vender e a gente, sim".

No período em que estive em campo, o preço da farinha de mandioca estava alto e o do cacau, baixo ${ }^{40}$. Ainda que isso fosse circunstancial, os indígenas sublinhavam que sua sobrevivência havia sido garantida, historicamente, pela mandioca, de certa forma à margem do cacau. Desde fins do século XIX, os indígenas passaram a cultivar cacaueiros, mas eram quase sempre "moitinhas de cacau", que pouco aportavam à renda das famílias. "Eu criei esses filhos tudo não foi no cacau, não. Foi fazendo farinha". Da mandioca, produziam uma expressiva quantidade de derivados, principalmente farinha, que se destinavam ao autoconsumo e à comercialização nas feiras da região41.

\begin{abstract}
Eu vendia puba, massa de aipim, massa de beiju, beiju em tira, beiju de goma, beiju de massa, beiju na palha, beiju cozido, beiju seco - toda diversidade de beiju eu fazia -, farinha de goma, banana. Até coco-de-manévelho [tucum] eu vendia, a centavos. Eu catava chuchu, eu pegava cebola, folha de couve, banana, fruta-pão, pimenta-malagueta, cumarinho, pimenta-de-cheiro, tudo, e levava para a feira, para vender. Quando eu chegava, vinha uma jega carregada - carregada de feira, eu trazia. Largava o couro, mas meus filhos não passavam fome. Eu passava o dia inteiro na casa de farinha e tinha uma ruma de freguesa. Vendia tapioca, polvilho, goma fresca, goma seca...
\end{abstract}

\title{
Mesmo as mandiocas diminutas, as "tamboeiras", não eram
}

\footnotetext{
${ }^{40}$ Ainda que o alto preço da farinha fosse favorável aos Tupinambá, grandes produtores que eram, ouvios comentarem: "A farinha está cara. Querem matar os pobres de fome? Pobre não come sem farinha".

${ }^{41}$ Vejamos, de forma muito sintética, como se dava a produção da farinha na Serra do Padeiro; para não me alongar, não mencionarei o processo de elaboração de outros derivados, como o beiju e a puba. Com o terreno preparado, planta-se a "maniba", como é referido o talo do vegetal; a partir de 10 meses (idealmente, 12), a mandioca poderá ser arrancada. Ela é então empilhada na casa de farinha, para ser "raspada", isto é, descascada - nesta etapa, o indivíduo ou família que estão produzindo a farinha costumam ser auxiliados por parentes, vizinhos e compadres. A mandioca é então sevada, isto é, ralada a motor, e depositada em sacos grandes, que são dispostos em uma prensa de madeira, para eliminação da manipuera. A massa é peneirada e ocorre então a "zazação", isto é, sua secagem, em um primeiro forno à lenha; em um segundo forno, a farinha é torrada. Ela é então peneirada novamente, sendo o "grolão" (os grãos grossos) mais uma vez passado no ralador. Uma série de cuidados observados durante a produção evita que a farinha fique "doce", "roxa" ou "vermelha". Para mais informações sobre o cultivo de mandioca pelos Tupinambá, ver Brasil (2009, p. 360-368).
} 
desperdiçadas: os indígenas deixavam-nas de repouso por um dia, para que fosse eliminada a "cianinha", isto é, o ácido cianídrico, e com elas alimentavam os animais de criação. Certa vez vi uma senhora aconselhando um rapaz: "Com a farinha, você faz sua feira de quinzena ou de mês. Quando desmancha uma roça, a outra já está chegando. Quem trabalha assim não quer trabalho de carteira assinada". No processo de retomada, a farinha tornava-se ainda mais importante, pois, sendo pouco perecível, podia ser produzida em grande quantidade e estocada para alimentar os indígenas durante períodos de enfrentamento mais ou menos prolongado. Uma farinheira em uma área retomada foi-me referida de forma afetuosa (ela foi quase humanizada na fala), pois dali saíram os sacos de farinha que sustentaram os indígenas em um dos períodos mais tensos do processo de recuperação territorial.

Realizar planejamentos econômicos quinquenais, detalhando as prioridades acordadas para o período, metas de produção e previsões acerca dos investimentos necessários para tanto era uma das atribuições da AITSP e dos coordenadores de retomada ${ }^{42}$. Aumentar o volume de cacau produzido, melhorar a qualidade das amêndoas e processá-las, de modo a agregar valor à produção, eram algumas das principais expectativas expressas nos documentos elaborados até 2012. Também se cogitava, no futuro, passar a produzir chocolate, em lugar de vender as amêndoas. Em uma assembleia realizada em fevereiro desse ano, em face de um informe apresentado pelo secretário da AITSP sobre a produção de cacau registrada em 2011, os indígenas concluíram que seria desejável (e factível) elevar em até seis vezes a média de arrobas de cacau por hectare. A concretização dessa perspectiva dependia, porém, de uma série de investimentos na recuperação de roças, aquisição de insumos, contratação de técnicos, reformas de barcaças, cochos de fermentação e estufas, bem como a construção de novas estruturas investimentos que os Tupinambá não tinham condições de realizar.

Em diferentes ocasiões, entidades governamentais e não governamentais discutiram com os Tupinambá possibilidades de

\footnotetext{
${ }^{42}$ A AITSP e os coordenadores realizavam também, uma ou duas vezes ao ano, reuniões de acompanhamento do planejamento quinquenal.
} 
transição à agricultura orgânica43. Os indígenas, porém, não levaram as propostas adiante: consideravam precipitado fazê-lo sem antes, em alguma medida, estabilizar a produção. Comentavam, ainda, que a permanência no território de áreas em posse de não índios, em que se seguiam práticas agrícolas convencionais, impossibilitaria uma adequada transição à agricultura orgânica. No período em que estive em campo, os indígenas adotavam algumas práticas consideradas orgânicas, sem, contudo, prescindir totalmente de agrotóxicos ${ }^{44}$. Acompanhei debates (internos e junto a não índios) em que alguns indígenas pontuaram a necessidade de introduzir alterações nas práticas agrícolas com vistas a reduzir os impactos ambientais verificados no marco da retomada territorial. Eles se referiam, mais especificamente, ao crescimento da população da aldeia, que demandava o aumento da produção de alimentos e o encurtamento do tempo de pousio. Nesse sentido, elaboraram, por exemplo, um projeto que previa a integração de galinheiros, hortas e roças de cacau, utilizando técnicas de compostagem. No fim de 2012, estavam discutindo junto ao governo estadual possibilidades de financiamento para tanto.

Durante o período em campo, ouvi os indígenas referirem-se também a um conjunto de atividades produtivas que gostariam de começar a desenvolver na aldeia. Nas represas existentes nas áreas retomadas, por exemplo, poderiam ser estabelecidos criatórios de peixes; produzir polpas e doces de frutas, como açaí e cupuaçu, e criar animais de carga, como burros, também eram possibilidades discutidas. Mais uma vez, contudo, faltava capital - nestes casos em particular, seriam imprescindíveis a instalação de tanques-rede nas represas (para evitar os ataques de predadores como martim-pescador, socó-boi, garça, certas espécies de cobras e mesmo lontras), a aquisição de

\footnotetext{
${ }^{43}$ Um exemplo dessas tentativas foi o projeto Agroecologia em Terras Indígenas: Serra do Padeiro, Povo Tupinambá, Buerarema, BA, desenvolvido pela Associação Nacional de Ação Indigenista (Anaí) e pela AITSP, entre 2006 e 2007, com financiamento do MDA. Para um relato do projeto, ver Carvalho et al. (2010).

${ }^{44}$ Carvalho et al. indicam que o uso de adubos sintéticos e herbicidas na área deve-se à difusão de pacotes tecnológicos pela Ceplac, a partir da década de 1970 (CARVALHO et al, 2010, p. 180). Note-se que, nesse processo, o órgão promoveu ainda a substituição de sementes tradicionais, que os indígenas vem buscando reintroduzir.
} 
DANIELA FERNANDES ALARCON - "Construir uma outra aldeia”...

despolpadeiras e a recuperação de pastos e cercas 45 . Note-se, ainda, que os projetos de desenvolvimento econômico dos Tupinambá esbarravam também na falta de garantia, por parte do Estado, de condições básicas de infraestrutura. Duas casas de farinha, construídas por meio de financiamento público, estavam paradas (ou funcionando ocasionalmente com motor a diesel), por falta de energia, e os indígenas tinham de efetuar um longo desvio para escoar a produção agrícola, devido à ausência de uma ponte em certo trecho do rio de Una. Apenas depois de uma longa e custosa mobilização - que resultou, inclusive, na prisão de lideranças -, os indígenas conseguiram garantir o fornecimento de energia em toda a aldeia e a construção da ponte. Quando da conclusão deste artigo, a ponte ainda não havia sido terminada.

Que omissões do Estado emperram o desenvolvimento econômico da aldeia, observavam os Tupinambá, é óbvio - a violação dos prazos para conclusão do procedimento demarcatório é o entrave central. Contudo, eles enfatizavam também a relação entre a ação repressiva do Estado e sua autonomia econômica como povo. "Quando a gente produz três cachos de banana, eles matam a touceira para nós termos que pedir esmola", observou o cacique Babau em reunião na Secretaria de Direitos Humanos da Presidência da República (SDH/PR), em março de 2012, aludindo aos impactos das operações policiais violentas sobre a produção agrícola na Serra do Padeiro. "Percebemos que a estratégia deles [da polícia e dos fazendeiros] era nos empobrecer. Todo mês de plantio, tinha ataque". Além de causar destruição direta da produção (com o incêndio de roças e a apreensão de ferramentas de trabalho), essas ações obrigaram os indígenas a suspender investimentos agrícolas. Tinham de recuperar o que fora perdido e gastar para se defender - por exemplo, contratando um advogado e financiando a ida de lideranças a Brasília para denunciar o que ocorria na aldeia. Com isso, o planejamento agrícola elaborado por eles não pôde ser cumprido, impactando na renda auferida pelas famílias até 2012 .

Esse raciocínio levou os Tupinambá a formularem uma exigência

\footnotetext{
45 Apesar da ausência de despolpadeiras, em 2012, algumas indígenas produziam polpas de frutas, principalmente de cupuaçu. As polpas - cuja extração era deveras trabalhosa, feita manualmente, com o auxílio de tesouras - eram comercializadas apenas na aldeia, destinadas em grande medida à alimentação escolar.
} 
ao Estado brasileiro: que este reparasse sua ação deletéria, investindo na recuperação agrícola da aldeia durante três anos, sentando assim as bases para seu posterior desenvolvimento autônomo. Até a conclusão deste artigo, o Estado respondeu a essa exigência apenas com propostas de apoio financeiro a projetos pontuais. Com isso, descaracteriza a demanda em seu conteúdo político - qual seja o reconhecimento de que o Estado cometeu uma violação e, portanto, teria de repará-la - e não garante as condições básicas para um desenvolvimento dos Tupinambá que seja, segundo as concepções indígenas, autônomo de fato.

\section{"O sangue puxa": algumas trajetórias}

O levantamento das histórias de vida dos indígenas moradores das retomadas e de alguns sítios, bem como a produção de diagramas genealógicos, realizados por meio de entrevistas e conversas informais, permitiu-me conhecer as trajetórias de grande parte dos sujeitos atualmente envolvidos no processo de retomada na Serra do Padeiro. Em meio às particularidades presentes nas narrativas, pode-se identificar alguns padrões. Se, de um lado, não faz sentido utilizá-los para enquadrar as histórias de indivíduos ou famílias em particular, de outro, eles nos ajudam a observar recorrências, compreensíveis à luz da história de expropriação territorial e de resistência indígena que tiveram lugar na região. Vejamos uma descrição sumária desses padrões, antes de nos debruçarmos sobre um conjunto de trajetórias exemplares.

1. A penetração dos não índios na região atuou no sentido de dispersar os indígenas - são as histórias sobre os índios que vagavam de um lado a outro, sem ter onde se fixar em definitivo. Para os Tupinambá da Serra do Padeiro, os deslocamentos explicam-se tanto pela "bruna do caboclo" (isto é, seu humor inconstante, dado a repentes inexplicáveis e ideias fixas) e por infortúnios ("quando mãe faleceu, pai se desgostou e fomos embora da terra"), quanto pela perseguição operada pelos não índios e por constrições materiais. 
2. A perda ou o encolhimento das terras próprias empurrou muitos indígenas às fazendas (inclusive as que terminaram retomadas). Note-se que a convivência nesse espaço suscitou uma aproximação entre índios e não índios pobres (que aí se desempenhavam como vaqueiros, trabalhadores do cacau, meeiros...), levando em alguns casos a casamentos interétnicos. Daí decorre que alguns dos mais engajados participantes do movimento de retomada não se reivindiquem indígenas - embora se possa dizer que, na condição de cônjuges, pais e mães de índios, bem como de membros da aldeia, tenham passado, geralmente, a partilhar a identidade indígena.

3. Uma conjunção de discriminações, como sói acontecer - neste caso relacionadas a etnia, gênero e classe social -, tornou a condição de trabalhadora doméstica recorrente para meninas e mulheres indígenas que tiveram de trabalhar fora da roça. Escusado dizer que o "serviço em casa de família", na ampla maioria das vezes, não compreendia relações de trabalho formalizadas. "Ô, minha filha, de tudo que passamos, essa foi a parte pior", disse-me uma indígena a respeito da saída dessas mulheres. Muitos relatos aludiam também às índias que vagavam "desamparadas", tendo de sustentar sozinhas a si e aos filhos ("menino nas costas, menino andando, menino doente", "onde passava, ela dava um menino"). Em alguns casos, comentavam, elas teriam sido forçadas a se prostituir, ao passo que outras terminaram por se envolver em relacionamentos indesejados com não índios, marcados, quase sempre, pela violência.

4. A periferia foi (e segue sendo) o destino dos que decidiam se mudar para a cidade. Eram diversas as possibilidades: Sururu (Vila Operária) e Vila Brasil, pequenos aglomerados na zona rural de Buerarema e Una, respectivamente; as zonas urbanas de São José da Vitória, Buerarema, Itabuna e Ilhéus; municípios da chamada "costa do descobrimento", como Santa Cruz Cabrália; municípios do centro-sul, notadamente São Paulo, Guarulhos e Vitória. Em seu jogo de atração/ilusão, a cidade é comumente caracterizada nas falas dos índios como elemento dificultador da organização indígena, espaço de onde se deveria "resgatar" os parentes que lá ainda vivem. É também uma alternativa com a qual se acena para aqueles desgostosos com o "regime da 
aldeia": "Para quem não quiser ficar aqui, tem muita favela para ir", disse uma indígena durante uma reunião.

Vejamos o caso de um índio, aqui referido como Manezinho, que viveu a típica trajetória Serra do Padeiro (posse própria) - "lá fora" - Serra do Padeiro (retomada). Manezinho nasceu em 1933, "nessas bocadas aí dentro", isto é, na mata, neto do Velho Nô (um dos "troncos velhos", isto é, um dos principais antepassados reivindicados pelos indígenas), filho de um índio e de uma não índia, cuja família era gente vinda "do norte". Quando a mãe de Manezinho morreu ("penando", de parto), ele era "molecote ainda". O pai, que na Serra do Padeiro detinha a posse de uma área com cerca de 280 ha, herdada do Velho Nô, encantou-se pela rua e partiu.

\footnotetext{
Meu pai vendeu tudo [as terras], para ir para a rua. Vendeu não, deu, porque antes não tinha preço de nada. Ele deu, trocou por casa velha, porcaria - quando foi ver, caiu uma parede [da casa]. Aí, pronto, perdeu as casas, perdeu tudo.
}

Manezinho não acompanhou o pai. "Fui criado no mundo, perdido". Andou por muitas partes, trabalhando em fazendas de cacau, inclusive nas terras de Gileno Amado. Aprendeu a bater facão, cantar vaquejadas (recentemente, compôs uma em homenagem ao cacique Babau) e fez "um bocado de filho por aí, esparramado". Durante cerca de seis anos, viveu "em uma fresta que tem lá em riba, na Serra do Padeiro", em uma área que em 2012 encontrava-se em posse de um não índio. Como ele não tinha terra onde parar, refugiou-se perto do pico, que, apesar de cercado pelas fazendas de não índios, continuava pouco devassado. No interior de uma loca de pedra, armou uma cama de vara, forrada de folhas, e acendeu um fogo à entrada do abrigo. "Minha vida era caçar e pescar. Quando precisava, dava um dia a um, dois dias a outro [isto é, trabalhava na diária]". Em 2012, Manezinho vivia em uma área retomada. "Agora eu não trabalho para ninguém mais, só mesmo é andar, pescar e dormir".

Em contraponto às várias situações de expulsão do território, que se expressam nos padrões elencados anteriormente, muitas são as falas em que o arraigo aparece como um valor fundamental. "Todo mundo 
DANIELA FERNANDES ALARCON - "Construir uma outra aldeia”...

tem que ter sua casa", disse-me uma senhora tão logo iniciei o trabalho de campo. Se os Tupinambá da Serra do Padeiro foram incumbidos, pelos encantados, de zelar pelo território, não cabem dúvidas sobre onde essa casa deveria ser. Emergia daí uma vigorosa tendência identificável no marco do processo de retomada: o retorno. "Daqui nós não podemos sair, da beirada do rio: sai, mas tem que voltar", disse uma senhora indígena, nascida em 1933, que vivia junto ao rio de Una. Depois que dois de seus filhos, já adultos, morreram afogados bem diante de sua casa, ela fechou permanentemente todas as janelas que davam para o rio. Mas eram essas águas que lhe constituíam ("ela precisa comer, toda semana, o peixinho dela", disse um sobrinho), de modo que a necessidade de permanecer ali era incontornável. Contando-me sobre um "caboclo velho" que vivia então na Serra das Trempes e manifestou o desejo de se mudar para uma retomada na Serra do Padeiro, o cacique Babau explicou-me: "Ele nasceu aqui, atrás da serra: isso, a pessoa nunca esquece".

É certo que retornos sempre existiram - mesmo nos momentos críticos da expropriação, alguns indígenas que persistiram no território cumpriam um papel centrípeto. Ouvi depoimentos de indígenas que tinham deixado a Serra do Padeiro, mas, de quando em quando, transpunham longas distâncias, para chegar à casa de João de Nô (João Ferreira da Silva), que herdou de seu pai, o Velho Nô, os poderes de rezador. Uma de suas netas, que nasceu em Olivença, lembra: "Mãe enchia um burro de meninos e vinha: dois num caçuá, dois no outro, um no meio. O dia todo andando. Quem podia, andava; quem não podia, ia no burro". No interior da casa de João de Nô, havia um fogo de chão sempre aceso, junto ao qual ele rezava as pessoas e onde os índios se reuniam para ouvir as histórias velhas, enquanto tomavam café e comiam batatas, aipim e abóbora assados no borralho.

Além dos retornos na forma de visitas (em dias santos, por ocasião de doenças ou sem mais), havia os casos em que era preciso dar abrigo a um parente ou a um conhecido em severas dificuldades algumas famílias abrigaram em suas casas levas de agregados. Em dado momento, por exemplo, João de Nô acolheu um de seus irmãos, Belisário Ferreira da Silva (Zé Hortênsio), que havia entregado sua roça na Serra do Padeiro (ao que parece em troca de uma mala ou um 
relógio) e saído pelo mundo. "Ele foi, pensou que ia se dar bem; chegou lá, não era nada daquilo, teve que voltar". Pediu guarida ao irmão mais velho, que the disse para escolher um lugar e botar sua roça. Zé Hortênsio e sua esposa passaram cerca de um ano morando sob uma grande pedra, no pé da serra, até construírem um rancho. Mas um retorno que se pretendesse muito mais amplo (na recomposição de um povo) e definitivo só se tornou possível no processo de retomada. Com as retomadas, "esse povo que estava perdido pelo mundo, andando, pôde voltar". Referindo-se ao fato de as retomadas terem possibilitado a reunião da maioria de seus irmãos, antes dispersos, uma senhora comentou:

Eu luto para minha família ter onde ficar. Porque já chegou ao ponto até do meu pessoal dormir no meio do tempo, sem ter um teto para ficar. A pior coisa é ver seu irmão, sua irmã sair com um cacaio [alforje] nas costas sem saber para onde ir. Eu ficava assim olhando: 'meu deus do céu, o que é isso, que justiça é essa?'. Eu me padecia por causa delas [das irmãs]. Hoje eu luto pela terra e quero terra para ter todos os meus parentes dentro.

Conversávamos três senhoras indígenas e eu, quando uma delas observou: "Se não aparecesse esse movimento, não tinha mais ninguém aqui". Antes do início do processo de retomada, uma delas vivia na fazenda Bom Jesus, recuperada em 2006, onde no passado funcionou a Agrícola Cantagalo. O que seu cônjuge recebia era pouco e eles não estavam autorizados a colocar uma roça para si: "Lá na firma, os homens não davam terra para ninguém trabalhar. A comadre, que já não tinha, ainda me deu um pedacinho [de terra, em um sítio] para plantar feijão". As duas outras moravam em áreas próprias, porém, muito reduzidas. "Nós já estávamos comprando mandioca dos outros, para fazer beiju e vender na feira, porque não tínhamos mais lugar para plantar. Era comprar para não morrer de fome".

Trata-se, agora, de um retorno que se projeta no futuro e é também um grande retorno imaginado, expresso em conjecturas: "eu fico pensando como seria se esse povo todo voltasse para cá, para retomar, a força que nós teríamos". Nota-se, assim, a disposição e o esforço de atrair os parentes dispersos. É comum encontrar pais e mães 
ansiando (e já planejando) a volta de filhos e netos que vivem fora. Certa vez, o cacique Babau mencionou a situação de um ramo de sua família, para explicar o imperativo de retomar: como ele e os seus poderiam estar tranquilos, vivendo em seu sítio, sabendo que uma porção de seus parentes estava dispersa e atravessando dificuldades? Ele se referia, naquele momento, aos descendentes de Ana Zilda Ferreira da Silva (e aos familiares destes), filha de João de Nô e de uma índia chamada Maria Evangelista. Eram mais de 20 pessoas, que retornaram à Serra do Padeiro em sucessivas levas, e, em 2012, viviam em quatro retomadas.

Ana Zilda, mais conhecida como Jandira, nasceu na Serra do Padeiro, junto a um pé de dendê, e, ao morrer, em 1982, ali foi enterrada. Perambulou por boa parte do território - viveu em lugares como a Serra das Trempes, Serra do Serrote, Santaninha, Olivença e Pedras de Una -, sustentando os filhos quase sempre sozinha. Uma filha mudou-se para outro estado, outra desapareceu, filhos e filhas trabalharam em fazendas. A história de Jandira repetiu-se, em grande medida, na trajetória de uma das filhas e, novamente, com a filha desta filha. "Minha mãe criou a gente em fazenda dos outros. Os fazendeiros tomaram a liberdade de cada um de nós", disse-me essa neta de Jandira, a que chamarei de Lena e que em 2012 vivia em uma retomada. Lena nasceu na Serra das Trempes, em 1978. Como precisasse ajudar a mãe com as despesas, a certa altura, deixou os dois filhos pequenos com o ex-cônjuge e foi atrás de uma promessa de emprego, em São Paulo. "Só fui com o dinheiro da passagem, mais nada". Ela morava no local de trabalho, a jornada durava todo o dia e o salário não chegava.

Eu saí procurando o que nunca ia encontrar. Encontrei muito foi trabalho, meu trabalho de graça. Você não comer direito, você não dormir direito... Você tem que ficar quietinho para não colocarem você na rua. Eu, em São Paulo, não tinha aonde ir - eu ia para onde? A mulher disse que pagava 150 reais de salário; no final de um mês, ela deu cinco. Eu ligava para mãe, mãe chorava. Eu tinha que tranquilizá-la: "calma, mãe, eu vou conseguir sair daqui".

Em certos casos, o retorno mais se assemelhava a um "resgate". Muitas vezes me contaram a história de duas indígenas que viviam uma situação dramática no interior de São Paulo, já que seus cônjuges estariam 
DANIELA FERNANDES ALARCON - "Construir uma outra aldeia”...

supostamente envolvidos com o tráfico de drogas, e elas "espiritaram", isto é, enlouqueceram. "Os encantados não gostam que a gente fique longe da aldeia", disseram-me. Em 2009, os indígenas foram buscá-las para viver em uma fazenda recém-retomada - junto aos filhos, somavam 11 pessoas. Algumas vezes vi o cacique Babau censurar enfaticamente o fato de uma delas haver retornado para São Paulo algum tempo depois. Ao deixar a aldeia, segundo ele, os indígenas expõem-se a riscos graves, já que sua inserção na cidade é necessariamente subalterna: podem vir a passar fome, envolver-se em atividades criminosas (notadamente o tráfico de drogas), prostituir-se ou se tornar trabalhadores escravos. Alguns casos de indígenas que viveram situações-limite servem-lhe para confirmar o argumento.

O processo de retomada, indicam os indígenas, também propiciou que parentes que não se conheciam terminassem por se encontrar. $O$ caso da indígena que chamarei de Alice é um exemplo. Tão logo se iniciou o processo de retomada na Serra do Padeiro, isto é, em 2004, ela se mudou para uma fazenda recuperada. Sua mãe, que aqui será dona Angelina, nascera na Serra das Trempes, filha de uma índia da Serra do Padeiro. Porém, ainda criança, dona Angelina perdeu os pais e foi levada por uma não índia para a cidade, onde Alice nasceu. "Quando Babau começou a fazer retomada, mãe veio a conhecê-lo; eles eram parentes, mas não sabiam". Preocupada com a situação de Alice na cidade - seu cônjuge bebia muito, trabalhava pouco e os filhos do casal "até adoeciam de fome" -, dona Angelina aconselhou a filha a participar do movimento. Foi a partir daí que a história da família, que remonta a um dos companheiros de Marcellino, abriu-se a Alice. Seu caso indica ainda como as notícias da realização de retomadas circulam pela região, fazendo com que indígenas de diferentes famílias se engajem no processo. Quando perguntei a um casal que vivia na fazenda Futurosa, retomada em 2008, como se iniciara sua participação no movimento, eles me contaram que trabalhavam na feira junto a uma indígena da família do pajé e que, por meio dela, recebiam notícias das retomadas. Sendo indígenas e acreditando na justeza das ações, decidiram participar.

Além dos dois grandes troncos a que acabo de me referir, uma terceira linhagem chegou à aldeia no contexto de retomada, mais precisamente em 2006. Passados seis anos, a família extensa 
encontrava-se presente em cinco áreas retomadas; vejamos brevemente sua história. Seu Hermínio dos Santos Sales nasceu em 1935, filho de indígenas que tinham uma "terrinha" na Serra das Trempes. Quando estive em campo, seu estado de saúde impedia-o de contar detalhes sobre sua trajetória. O que se sabe é que, a certa altura, partiu para o Rio de Janeiro, para "fazer a vida". Lá, conheceu dona Maria José Gomes de Lima, uma índia kambiwá nascida na Baixa da Índia Alexandra, no sertão pernambucano, em 1946. Dona Maria deixara sua família em 1964, transferindo-se para o Rio de Janeiro, onde se empregou como trabalhadora doméstica.

A vida era muito sofrida - eu me acabava na roça, a roupa que eu vestia era de saco. Aí eu disse: "Mãe, eu vou-me embora para o Rio. Mas eu peço à senhora uma coisa: pelo amor de deus, não me rogue praga, não, me deixe ir". Aí a minha irmã falou: "Vai, deixe ela ir, essa rapariga".

Seu Hermínio e dona Maria casaram-se. Depois do nascimento da primeira filha, mudaram-se para Arcoverde, em Pernambuco, e lá dona Maria soube que seu Hermínio também era índio. Ele, contudo, perdera o contato com os parentes. "A mãe dele muitas vezes acendia vela e rezava para ele, pensando que ele estava morto", contou-me dona Maria, baseando-se no relato de uma irmã de seu Hermínio. Um dos filhos do casal lembrava:

Sempre ele [seu Hermínio] chorava. Ele contava para nós que sabia o dia em que a mãe e o pai dele iam morrer. Tinha duas estrelas no céu, e ele dizia: "olha, aí são meu pai e minha mãe; no dia em que essas estrelas morrerem, meu pai e minha mãe morrem". E de fato... eu era pequeno, eu era criança, mas me lembro um pouquinho. Lá era um lugar em que não tinha energia - lugar em que não tem energia e não chove muito, o céu fica bem estrelado, bem estrelado mesmo. A gente sempre sentava ali fora e ficava olhando; ele ficava olhando para as estrelas e chorando. Um dia ele foi para o mato mais mãe. Quando chegou no mato, caçando, acho que deu vontade de olhar para as estrelas. Só tinha uma, sozinha. Ele falou para mãe: "ou papai ou mamãe já morreu; ou pai ou mãe eu não tenho mais, um dos dois já foi". Ficou uma estrela só. Depois de muito tempo 
DANIELA FERNANDES ALARCON - "Construir uma outra aldeia”...

essa estrela morreu. Ele começou a chorar... chorou, chorou. Ele ficou com aquilo na cabeça e adoeceu de derrame. Então ele disse: "eu vou acabar meu resto de vida na minha terra".

Com essa decisão, iniciou-se uma jornada de retorno, repleta de percalços, que durou anos. Finalmente, com mais de 70 anos de idade, seu Hermínio conseguiu chegar ao território de onde saíra aos 18. Por meio de um anúncio no rádio, localizaram familiares - seus pais, de fato, já haviam morrido e ele ficou "sem direito na terra" da Serra das Trempes. A notícia de que havia uma família de índios vivendo na periferia de São José da Vitória chegou à Serra do Padeiro; depois de algumas conversas, envolvendo principalmente discussões genealógicas, eles se instalaram em uma retomada. Um a um, os filhos do casal foram atraídos para a TI, espalhando-se por várias retomadas; em 2012 apenas dois deles não viviam na Serra do Padeiro. Em junho de 2012, um sobrinho de dona Maria, casado com uma índia kapinawá, também se mudou para a aldeia. Quando saiu da Baixa da Alexandra, dona Maria não imaginava que tornaria a viver em aldeia; olhando em retrospecto, contudo, considerava sua trajetória compreensível: "o sangue [indígena] puxa".

Assim como seu Hermínio e dona Maria, índios de outras regiões da $\mathrm{TI}$ e mesmo de outros povos mudaram-se para a Serra do Padeiro, tanto no contexto de retomada, como em períodos anteriores. Dona Maria da Glória de Jesus, cônjuge de seu Lírio, o pajé da aldeia, nasceu em 1955, filha de uma índia kariri-sapuyá. Sua mãe, Hilda Rosa de Jesus (Nita), nasceu provavelmente no início da década de 1940, na Reserva Indígena Caramuru-Catarina Paraguaçu. Já a mãe de Nita teria nascido em Itiruçu, ao norte de Jequié. É para essa região que foram "descidos" os Kariri-Sapuyá, oriundos de Pedra Branca, ainda no século XIX; no fim dos anos de 1930, parte deles transferiu-se, a conselho do etnólogo Curt Nimuendaju, para a RI Caramuru-Paraguaçu46. Com o pai, negro, dona Maria não conviveu. O homem só conseguiu se deitar com Nita que trabalhava para ele em uma quinta de café - depois de presenteá-la com um corte de tecido enfeitiçado. "Minha mãe me pariu chorando e xingando", contou-me, para indicar o abandono paterno. Quando dona

${ }^{46}$ Ver Carvalho (2011, p. 383-384). 
DANIELA FERNANDES ALARCON - "Construir uma outra aldeia”...

Maria conheceu o pai, aos seis anos de idade, ele the deu um minúsculo frasco amarelo de perfume, mas não o sobrenome. Já adulta, ela tornou a vê-lo; ele the disse que ela poderia pedir o que quisesse, mas ela já não queria nada: "Nasci nua, já estou vestida", teria respondido. "Minha história de negro, eu não sei contar. Já minha história de índio eu sei contar por causa de Mãe Velha [a avó materna]".

Como tinha de sustentar a si e aos filhos, aonde havia trabalho, Nita ia. Isso explica por que dona Maria nasceu em Nova Canaã, no sudoeste da Bahia, longe do posto indígena Caramuru. Dona Maria lembra-se de uma sucessão de ocupações, ao lado da mãe: "trabalhei desde que nasci". Quando dona Maria era recém-nascida, Nita trabalhava em fazenda de café ("mãe me levava para a roça e tinha que me deixar lá, com os jatiuns [mosquitos] me mordendo"). Mais tarde, a mãe passou a lavar roupa de ganho e dona Maria se encarregava dos panos menores. Em seguida, as duas trabalharam quebrando pedras (ao que parece, em uma jazida de mármore azul que foi explorada no interior da RI Caramuru-Paraguaçu). Depois de passar por diferentes municípios do sudoeste e do sul da Bahia, as duas chegaram à região da Serra do Padeiro, onde dona Maria casou-se, estabelecendo-se no sítio onde vivia em 2012. Até sua morte, Nita viveria de sítio em sítio, de fazenda em fazenda.

Uma prima em segundo grau de dona Maria da Glória, também ela Pataxó Hã-Hã-Hãe (note-se que este etnônimo englobante inclui os Kariri-Sapuyá), vivia na fazenda Serra das Palmeiras, retomada em 2010, casada com um indígena nascido à beira do rio de Una. Cecília, como me referirei a ela, nasceu na fazenda pretensamente pertencente a um homem chamado Valdivino, localizada em Itaju do Colônia e retomada em 2012 pelos Pataxó Hã-Hã-Hãe. "A minha avó materna morou dentro do posto dos índios [na RI Caramuru-Paraguaçu]. Mas eles não tinham condições de fazer casa, nem nada, aí iam trabalhando em fazenda dos outros". Por medo, esta avó impedia os netos de dizerem que eram índios. Como vivia em uma fazenda de gado, a família de Cecília não podia colocar roças ou hortas próprias e, portanto, tinha muitos gastos com alimentação. Aos oito anos de idade, Cecília começou a trabalhar como babá, em uma fazenda próxima. Seu pai morreu, trabalhando para Valdivino, e então sua mãe recebeu do fazendeiro uma casa em Itaju do 
DANIELA FERNANDES ALARCON - "Construir uma outra aldeia”...

Colônia ("era um caramanchão grande, aberto, sem paredes") e passou a trabalhar como lavadeira. Quando uma filha da casa onde Cecília trabalhava desde os oito anos mudou-se para Salvador, para estudar, mandaram-na junto, para servi-la (ambas tinham a mesma idade). "E sempre quando nascia alguém da família, eu ia tomar conta". Trabalhando em casas de família, viveu também em Itabuna e Itamaraju. Já adulta, terminou por conhecer dona Maria da Glória, pois a irmã desta, sabendo que tinham parentes em Itaju do Colônia, saiu à procura deles. No contexto de retomada territorial, assim como outros índios, Cecília ingressou na universidade e se tornou professora na escola indígena.

Em uma das retomadas, vivia um indígena a que chamarei de João, que tinha 45 anos de idade quando o entrevistei e que havia nascido no Cururutinga, outra região da TI. Na infância, vivia com a família na "terrinha" de um avô, onde trabalhavam para si; quando tinha sete anos de idade, sua mãe morreu e a família se mudou para Ilhéus. As irmãs tiveram de trabalhar em casa de família e João logo iniciou a típica jornada de fazenda em fazenda. "Eu sei bem que quando eu estava com a idade de 14 anos, eu já estava trabalhando fichado [registrado como aprendiz] na fazenda". Trabalhando em fazenda, enfermou-se. Depois de uma passagem por uma retomada no Acuípe de Cima (à qual não se adaptaram), João e a família decidiram se mudar para a Serra do Padeiro, onde viviam em 2012. "Aqui só estamos eu e a família [elementar]. Parente por parte de pai e mãe... eu não tenho parente nenhum por aqui".

Sua situação era semelhante à do indígena que aqui será Miguel, morador de outra retomada. Filho de uma índia de Olivença que o deixou no mundo quando ele tinha dois anos de idade - morreu ao dar à luz um filho mais novo, vítima de feitiçaria -, Miguel chegou ao BeiraRio, na região da Serra do Padeiro, aos 17 anos de idade, junto ao pai. "Pai era andarilho e, como eu não me dominava, tinha que ir junto; pequenininho, já trabalhava, pai colhendo [cacau] e eu bandeirando [reunindo os frutos derrubados]". Do Beira-Rio, Miguel recusou-se a sair e o pai acabou ficando também; casou-se e, em 2012, sua família extensa estava espalhada por quatro retomadas na Serra do Padeiro. Talvez tivesse parentes em Olivença ("deve ter, porque parentagem nunca se acaba"), mas não sabia quem eram.

Desde 2007, o indígena a que chamarei Otávio vivia em uma 
DANIELA FERNANDES ALARCON - "Construir uma outra aldeia”...

retomada na Serra do Padeiro, com sua esposa, uma não índia que aqui será Catarina, e um de seus dois filhos. Otávio, que em 2012 tinha pouco mais de 60 anos, praticamente não dispunha de informações sobre sua família. Sabia apenas que havia nascido em Itajuípe e que chegou à Serra do Padeiro com dois anos de idade. Foi um dos últimos indígenas a viver em uma loca de pedra, junto a Zé Hortênsio, a que me referi há pouco, e cresceu em meio à família de João de Nô. Catarina, por sua vez, vivia "que nem escrava". Natural de Valença, chegou à Serra do Padeiro junto a um tio, que, depois de comprar terras na região, buscou a menina para trabalhar para ele. "Eu rachava estaca, cortava de machado, carregava nas costas, fazia cerca, amansava burro, amansava boi. E ele [o tio] nunca me deu nada". Depois de se casar com Catarina, Otávio se mudou para a fazenda, mas logo ficaram sem lugar. "Meu tio disse que ia vender [a fazenda] e me dar a metade do dinheiro. Não deu nem a terça metade". Mudaram-se para Uruçuca, para trabalhar em fazenda. Otávio adoeceu, deram um jeito de voltar para Buerarema, mas não se acostumaram a viver "na rua". Instalaram-se na casa de compadres, na Serra do Padeiro, e depois conseguiram autorização para fazer um "barraco" e pôr roça em uma fazenda próxima ao centro da aldeia. Ali viveram até se mudarem para a retomada.

Com a retomada da Unacau, em maio de 2012, mudou-se para lá um jovem indígena, filho de pai desconhecido, que, ainda menino, fora enjeitado pela família da mãe (do tronco dos Ferreira da Silva/Bransford da Silva). Muito "judiado", desde pequeno vivia corrido pelos matos, com medo de tudo. "Resgatado" pelos parentes no contexto de retomada, continuava "cismado", mas participava das atividades coletivas e logrou se estabelecer à sua maneira. Seu caso permite indicar algumas diferenças entre sítios e retomadas. Ainda que ambos fossem partes de um mesmo território, que estivessem unidos em um circuito de reciprocidade e que houvesse alguma mobilidade entre eles, o sítio era diretamente associado a uma família extensa. Isso não quer dizer que critérios de parentesco não estivessem envolvidos na distribuição dos indígenas nas retomadas, como já comentei. Tampouco que os chefes de lugar (esta não era uma expressão corrente entre os Tupinambá da Serra do Padeiro, uso-a apenas na falta de termo melhor) se considerassem fora do raio de autoridade do cacique e do pajé. Mas, 
DANIELA FERNANDES ALARCON - "Construir uma outra aldeia”...

como também eles eram autoridades e tinham "direito" sobre seus sítios, ocorria de o regime de índio ser parcialmente suspenso nesses espaços. Os "crentes" que se recusaram a participar do toré, como indiquei, voltaram ao sítio familiar, no interior da TI, e não foram perturbados; índios que se casavam com não índios tampouco eram impedidos de viver nesses espaços. Ao mesmo tempo, os sítios eram mais restritivos em relação a quem poderia neles morar. Banido de sua família extensa, o rapaz que mencionei há pouco teria que contar com a sorte de ser aceito como agregado em outro sítio (desconheço se ele tinha padrinhos que o pudessem acolher, mas suspeito que não), viver em fazenda ou partir; só teria terra própria se fosse o fundador de um novo sítio, algo improvável no contexto fundiário local. Com o processo de retomada, outro tipo de inserção tornou-se possível.

Muitas vezes, cônjuges de índios considerados não índios (referidos como agregados), ao contar suas histórias de vida, diziam ser filhos ou netos de "índios sem definição". Tratar-se-ia de indígenas de várias partes (do sertão, dos arredores de Itabuna), cujas etnias não poderiam ser precisadas e que, por razões geralmente desconhecidas pelos descendentes, haviam perdido as relações com seus povos. Por exemplo, uma jovem nascida no sertão da Bahia e que vivia em uma retomada, junto a seu cônjuge, comentava sobre sua avó: "ela só diz que é índia, que muitos parentes morreram e que quando ela perdeu as terras dela, chegou a morar até debaixo de pé de pau". Outra mulher, nascida na região, estava ansiosa pela próxima visita ao pai, pois queria Ihe fazer novas perguntas, na trilha de sua ascendência indígena. Conheci também ao menos quatro indígenas que foram adotados por não índios, perdendo em grande parte (alguns, completamente) o vínculo com seus parentes, o que estão buscando recuperar no contexto de retomada.

Dessa pequena amostra de trajetórias, emergem indígenas que conhecem seus troncos velhos e outros que não têm como se referir a seus "primeiros avós" de forma precisa, já que vêm de outra parte, perderam o contato com seus familiares, nunca os conheceram ou estes estão mortos. Entre os não índios, há os que se apresentam como descendentes de indígenas, mas cujas trajetórias familiares não os levaram a assumir uma identidade étnica específica. Suas histórias, 
DANIELA FERNANDES ALARCON - "Construir uma outra aldeia”...

geralmente também marcadas pela violência expropriatória e pela exploração de classe - eram, fundamentalmente, "fracos", como sempre dizia Catarina -, haviam se cruzado com as histórias de indígenas, com quem terminaram por se casar. Quando esses índios e não índios contaram-me suas histórias de vida, todos estavam envolvidos, cada qual a sua maneira, no processo de construção da aldeia Serra do Padeiro. Como se comentou, a retomada territorial propiciou-lhes condições de estabelecer e fortalecer vínculos de solidariedade que não se baseavam somente em relações de parentesco, compadrio e vizinhança. Eles entendiam participar de um processo coletivo de resistência.

\section{Considerações finais}

Ao longo da última década, retomando fazendas, os Tupinambá vêm se tornando capazes de deixar as posições de subordinação que ocupavam na sociedade regional e de voltar a se dedicar às atividades que desenvolviam tradicionalmente, como agricultura em pequena escala, criação de animais, caça, pesca e coleta. Neste artigo, buscou-se demonstrar que tal processo vem permitindo, ainda, a manutenção e o fortalecimento de sua identidade e de seus laços sociais e territoriais. Engajados no processo de "construção da aldeia", os indígenas vêm engendrando um conjunto de regras (que podem ser mais ou menos formais) de apropriação do território e de convívio social, bem como modos de organização do trabalho. Além disso, vêm se esforçando para atualizar sua história e projetar a trajetória futura do grupo étnico. $\mathrm{O}$ "retorno da terra" mencionado nas profecias - e que pode ser entendido, mais amplamente, como o lento restabelecimento do vigor do território recuperado - é, simultaneamente, o retorno dos índios dispersos (os vivos e os mortos) e dos encantados, bem como a fundação das bases de um futuro imaginado.

\section{Referências bibliográficas}


ALARCON, Daniela Fernandes. O retorno da terra: as retomadas na aldeia Tupinambá da Serra do Padeiro, sul da Bahia. 2013. 272 f. Dissertação (Mestrado em Ciências Sociais) - CEPPAC, UnB, Brasília, 2013.

ASSOCIAÇÃO DOS ÍNDIOS TUPINAMBÁ DA SERRA DO PADEIRO. Carta da Aldeia Tupinambá da Serra do Padeiro à Secretaria de Desenvolvimento Social e Combate à Pobreza da Bahia. Aldeia Serra do Padeiro, 28 abr. 2008.

Ata da reunião dos coordenadores das roças comunitárias para avaliação de criação de normas das mesmas. Aldeia Serra do Padeiro, 24 maio 2009.

BRASIL. Ministério da Justiça. Fundação Nacional do Índio. Relatório final circunstanciado de identificação da Terra Indígena Tupinambá de Olivença. Brasília: Funai, 2009.

BRASILEIRO, Sheila. A organização política e o processo faccional no povo indígena Kiriri. 1996. 249 f. Dissertação (Mestrado em Antropologia) - FFCH, UFBA, Salvador, 1996.

CAMARA CASCUDO, Luis da. Dicionário do folclore brasileiro. Belo Horizonte: Itatiaia, 1984.

CARVALHO, Aurélio José Antunes de et al. Assistência técnica e extensão rural na comunidade indígena Tupinambá de Serra do Padeiro: experiência, desafios e possibilidades da capacitação sob a ótica agroecológica. In: ARAUJO, André Luiz de O.; VERDUM, Ricardo (Org.). Experiências de assistência técnica e extensão rural junto aos povos indígenas: o desafio da interculturalidade. Brasília: Ministério do Desenvolvimento Agrário, 2010. p. 173-195.

CARVALHO, Maria Rosário de. De índios "misturados" a índios "regimados". In: CARVALHO, Maria Rosário de et al. (Org.). Negros no mundo dos índios: imagens, reflexos, alteridades. Natal: Editora da UFRN, 2011. p. 337-358.

COROADAS de pleno êxito as observações sobre o eclipse feitas pelos cientistas norteamericanos em Bocaiúva. Folha da Noite, 20 maio 1947.

COSTA, Erlon Fábio de Jesus. Da Corrida de Tora ao Poranci: a permanência histórica dos Tupinambá de Olivença no Sul da Bahia. 2013. 201 f. Dissertação (Mestrado em Desenvolvimento Sustentável) - CDS, UnB, Brasília, 2013.

COUTO, Patricia Navarro de Almeida. Morada dos encantados: identidade e religiosidade entre os Tupinambá da Serra do Padeiro, Buerarema, BA. 2008. 169 f. Dissertação (Mestrado em Antropologia) - FFCH, UFBA, Salvador, 2008.

FERREIRA, Sonja Mara Mota. "A luta de um povo a partir da educação": Escola Estadual Indígena Tupinambá da Serra do Padeiro. 2011. 153 f. Dissertação (Mestrado em Educação) - PPGEDUC, UESB, Salvador, 2011. 
GARCEZ, Angelina Nobre Rolim. Mecanismos de formação da propriedade cacaueira no eixo Itabuna/Ilhéus - 1890-1930 (Um estudo de história agrária). 1977. 179 f. Dissertação (Mestrado em Ciências Humanas) - FFCH, UFBA, Salvador, 1977.

LOPES, Nei. Novo dicionário banto do Brasil. Rio de Janeiro: Pallas, 2003.

MACEDO, Ulla. A dona do corpo: um olhar sobre a reprodução entre os Tupinambá da Serra-BA. 2007. 205 f. Dissertação (Mestrado em Antropologia) - FFCH, UFBA, Salvador, 2007.

OLIVEIRA FILHO, João Pacheco de (Org.). Indigenismo e territorialização: poderes, rotinas e saberes coloniais no Brasil contemporâneo. Rio de Janeiro: Contra Capa, 1998.

SALOMÃO, Maria da Graça et al. Colubrid snakebite: a public health problem in Brazil. Herpetological Review, Clovis, EUA, v. 34, n. 3, p. 307-312, 2003.

SILVA, Edson Hely. Xukuru: memórias e história dos índios da Serra do Ororubá (Pesqueira/PE), 1950-1988. 2008. 299 f. Tese (Doutorado em História Social) - PPGH, UNICAMP, Campinas, 2008.

SILVA CAMPOS, João da. 2006. Crônica da capitania de São Jorge dos Ilhéus. Ilhéus: Editus, 2006 [1947].

TÓFOLI, Ana Lúcia Farah de. As retomadas de terras na dinâmica territorial do povo indígena Tapeba: mobilização étnica e apropriação espacial. 2010. $176 \mathrm{f}$. Dissertação (Mestrado em Sociologia) - PPGS, UFCE, Fortaleza, 2010.

UBINGER, Helen Catalina. Os Tupinambá da Serra do Padeiro: religiosidade e territorialidade na luta pela terra indígena. 2012. 190 f. Dissertação (Mestrado em Antropologia) - FFCH, UFBA, Salvador, 2012.

VIEGAS, Susana de Matos. Terra calada: os Tupinambá na Mata Atlântica do sul da Bahia. Rio de Janeiro: 7Letras, 2007.

WOORTMANN, Ellen F. Herdeiros, parentes e compadres: colonos do sul e sitiantes do Nordeste. São Paulo: Hucitec; Brasília: EDU-UnB, 1994.

WOORTMANN, Ellen F.; WOORTMANN, Klaas A. O trabalho da terra: a lógica e a simbólica da lavoura camponesa. Brasília: EDU-UnB, 1997.

WOORTMANN, Klaas. Com parente não se neguceia: o campesinato como ordem moral. Série Antropologia, Brasília, n. 69, 1988. 